\title{
Escavando um cemitério oitocentista em Porto Alegre, Rio Grande do Sul, Brasil
}

\author{
Archaeological research in a nineteenth century cemetery in \\ Porto Alegre, Rio Grande do Sul, Brazil
}

\section{RESUMO}

Este relato aborda o trabalho arqueológico realizado nos terrenos do antigo cemitério paroquial da cidade de Porto Alegre, Rio Grande do Sul, entre 2011 e 2012, como parte do restauro do edifício da Cúria Metropolitana. Participei da primeira parte dos trabalhos como auxiliar de campo e de laboratório, sendo responsável tanto pelas escavações quanto pelo levantamento histórico do local. Os objetivos da atividade eram o resgate de remanescentes ósseos humanos que pudessem ser encontrados durante as obras de restauro, bem como a redescoberta do antigo cemitério, parcialmente esquecido pela memória urbana da cidade. Foram encontradas dezesseis sepulturas in situ, além de algumas centenas de ossos dispersos, que seguem sob análise genética e antropobiométrica. A escavação serviu para trazer novamente à luz um espaço que foi importantíssimo para a cidade durante oitenta anos, mas que há mais de um século encontravase completamente esquecido. Serviu, igualmente, para estimular novas pesquisas, que buscaram uma análise mais crítica do pouco que existia escrito sobre este espaço.

Palavras-chave: Cemitério da Matriz de Porto Alegre - Arqueologia da morte Arqueologia cemiterial - Arqueologia histórica e urbana - Cemitério e memória urbana.

\begin{abstract}
The propose with this report is to provide the reader with an overview of archaeological work in the old parish cemetery in the city of Porto Alegre, Rio Grande do Sul, carried out between 2011 and 2012 as part of the restoration of the building of the Metropolitan Curia. I participated in the first part of the field work as a field assistant, responsible for both the excavations and by historical survey of the site. The research aimed to the recovery of human skeletal remains that perhaps could be found during the restoration work and the re-discovery of the ancient cemetery, partially forgotten by the urban memory of the city. Sixteen graves were found in situ addition of a few hundred dispersed bones, which follow in genetics and antropobiométrica analysis. The excavation has served to bring back to light a space that was very important to the city for 80 years, but that for more than a century, was completely forgotten. Served also to stimulate further research, who sought a more critical analysis of the little there was written about this space.
\end{abstract}

Keywords: Porto Alegre main church cemetery - Archaeology of death - Cemiterial Archaeology - Historical and urban Archaeology - Cemetery and urban memory.

* Doutorando e Mestre em História Social pela Universidade Federal do Rio Grande do Sul (UFRGS, 2016). CV: <http://lattes.cnpq.br/4630288133181336>. 
No filme O Sétimo Selo há um diálogo no qual o escudeiro de Antonius Block chama a um cadáver de "bastante eloquente". Ao historiador das mortalidades, incapaz de necromancia, é sujeita a busca de outras formas de diálogo com os seus tanatografados. No relato de experiência que apresento aqui, a forma escolhida foi a pesquisa arqueológica que, ao remover as camadas de aterro depositadas sobre o terreno no qual hoje se encontra o edifício da Cúria Metropolitana de Porto Alegre, evidenciou os restos mortais de alguns dos habitantes da cidade falecidos provavelmente em meados do século XIX.

O acompanhamento das obras de restauro, em conformidade com a legislação que regulamenta o impacto causado por empreendimentos às jazidas arqueológicas, ${ }^{1}$ foi solicitado pela empresa Arquium Construção e Restauro Ltda., responsável pelo projeto. As escavações foram coordenadas pela arqueóloga Angela Maria Cappelletti e contaram com a participação de diversos auxiliares e técnicos de campo. Permaneci por um ano, de outubro de 2011 a outubro de 2012, desenvolvendo funções de escavação, análise de material arqueológico e levantamento histórico. Tanto o trabalho de restauro como o arqueológico foram interrompidos em fins de 2012 por falta de verbas, havendo a possibilidade de serem reiniciados no futuro.

\section{O terreno e o edifício}

O primeiro cemitério de Porto Alegre foi construído atrás da igreja matriz Madre de Deus. ${ }^{2}$ A área total é incerta, mas pela documentação cartográfica e por algumas gravuras de época sabe-se que era um espaço bastante inclinado e um tanto inconveniente para um cemitério, visto a existência de relatos de sepulturas sendo erodidas pelas águas da chuva que rolavam morro abaixo (ver Figura 1). Tanto o é que em 1792 foi erguido um paredão de pedra de 30 metros de comprido por 20 de lado para resguardar o terreno. ${ }^{3}$

Há divergências quanto à data de construção da igreja matriz. A hipótese que defendo é a de que em 1769, enquanto a povoação do Porto dos Casais (antiga denominação de Porto Alegre) pertencia à freguesia de Nossa Senhora da Conceição de Viamão - à época capital da Capitania - foi erguida uma capela dedicada a São Francisco, por ordem do governador Marcelino de Figueiredo (Neis, 1972, p. 13). Uma vez separada a freguesia de São Francisco da de Viamão, em 1772, buscou-se ampliar essa construção para lhe dar ares de igreja matriz, ao mesmo tempo em que se iniciou uma arrecadação para a construção de uma nova igreja, cujas obras provavelmente se iniciaram em 1779/1780 (Balem, 1941, p. 62; Ferreira, 1971, p. 44).

1 Portaria n 230 de 17 de dezembro de 2002. Disponível em: http://portal.iphan.gov.br/uploads/legislacao/ Portaria_n_230_de_17_de_dezembro_de_2002.pdf. Acesso em 28/09/2016.

2 O primeiro santo padroeiro da povoação foi São Francisco, em 1772. Porém, já no ano seguinte, o orago foi alterado para a Madre de Deus por ser a santa, segundo Augusto Porto Alegre (1909, p. 39), madrinha do então governador José Marcelino de Figueiredo.

3 Esta informação consta em um artigo não assinado publicado no jornal Correio do Povo, em uma série de textos dedicados à história da igreja matriz colonial, então em demolição. MUSEU DE COMUNICAÇÃO SOCIAL HIPÓLITO JOSÉ DA COSTA (doravante MCSHJC), Correio do Povo, Porto Alegre, p. 4, 22/08/1920. É possível que o muro que circundava o prédio do Seminário Episcopal desde 1879 fosse o mesmo erguido no século XVIII para o cemitério, apenas ampliado. 
Figura 1: Gravura "Porto Alegre vista do sul", de Herrmann R. Wendroth, 1852

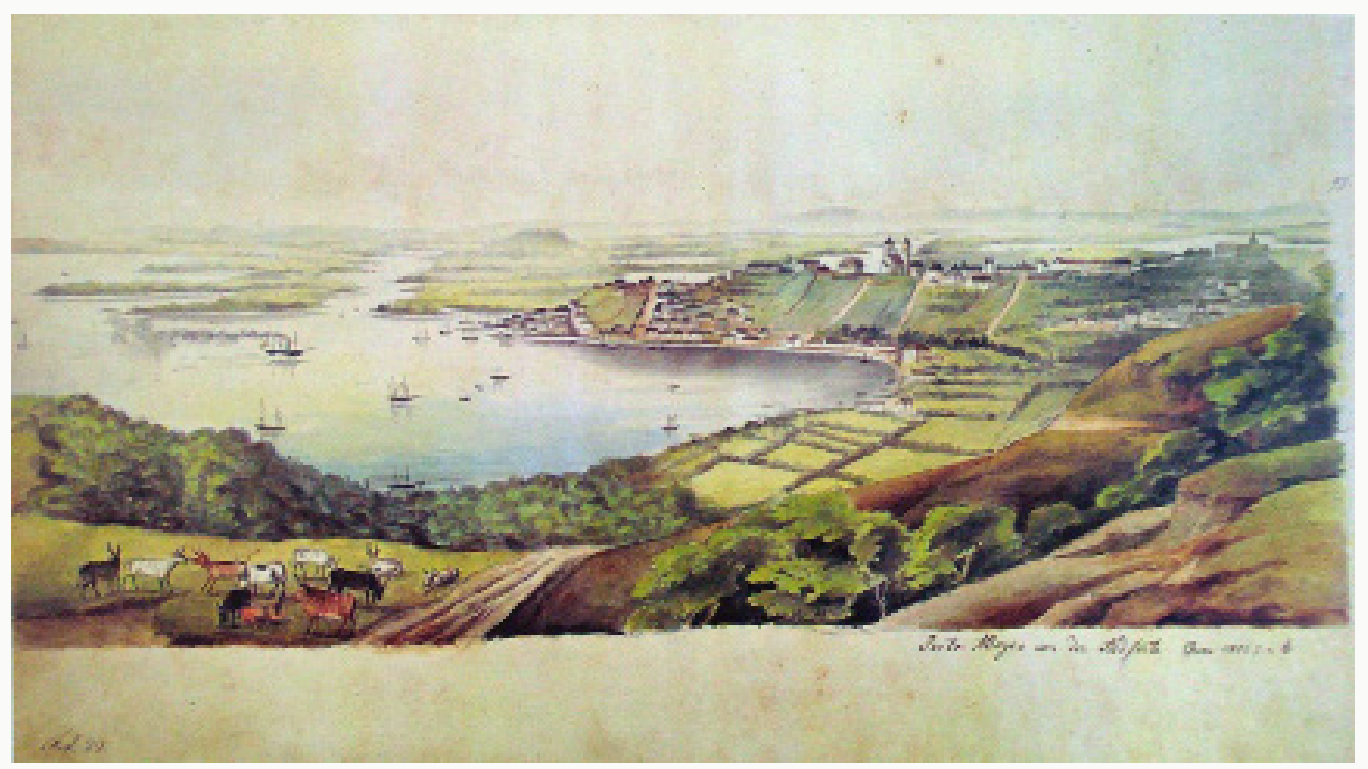

Fonte: O RIO GRANDE DO SUL EM 1852, 1982.

Entre 1773 e 1774 foram fundadas as primeiras irmandades de Porto Alegre, respectivamente, a de São Miguel e Almas (dedicada ao Arcanjo São Miguel e as Almas do Purgatório) e a do Santíssimo Sacramento e Madre de Deus, ambas responsáveis pela arrecadação de verbas para a construção do templo. Finda a igreja, essas irmandades receberiam a honra de ter seus consistórios localizados atrás das duas torres sineiras: São Miguel, no lado do Evangelho, e o Santíssimo, no lado da Epístola. No alto da torre mais oriental encontrava-se um cata-vento na forma de um anjo segurando uma balança e uma espada em chamas, para demarcar a geografia interna do templo, conforme pode ser visto na figura 2. A igreja ficava localizada entre o Palácio do Governo e a Capela do Divino Espírito Santo.

$\mathrm{Na}$ varanda do templo, em seu alpendre, sob sua porta e no seu interior, em diversos espaços, foram sepultados 1.761 cadáveres, que ocuparam sepulturas de irmandade ou de fábrica. O período de maior uso do templo como espaço de enterramento se dá entre 1773 e 1805, quando há um hiato de sete anos sem qualquer menção a covas ad sanctos (junto aos santos, isto é, dentro do templo) sendo utilizadas. Entre 1812 e 1814, há um novo pico de inumações dentro da igreja, mas esse último ano se constitui em um marco para o fim dos sepultamentos internos. Após 1815, até abril de 1850 - quando os sepultamentos foram transferidos para o recém-criado cemitério extramuros da Santa Casa da Misericórdia (Meirelles, 2010) -, somente ocorreriam 20 enterramentos bastante sui generis, mas que não abordarei neste relato, dedicado a analisar a experiência com as escavações das sepulturas do terreno 
externo da igreja. ${ }^{4}$ Analisei as sepulturas internas em minha dissertação de mestrado (Meirelles, 2016, p. 104-119), para a qual dirijo o leitor interessado em maiores detalhes. Como o espaço ad sanctos não foi alvo das investigações arqueológicas cuja experiência será aqui relatada, não tratarei mais dele no decorrer deste texto.

Figura 2: Procissão religiosa, final da década de 1910

São visíveis, da esquerda para a direita, os prédios do Império do Espírito Santo, da antiga igreja matriz e do Palácio do Governo. Como dito no texto, a torre mais à esquerda na fotografia possui, em seu cata-vento, a imagem do Arcanjo São Miguel, demarcando a localização do consistório dessa irmandade.

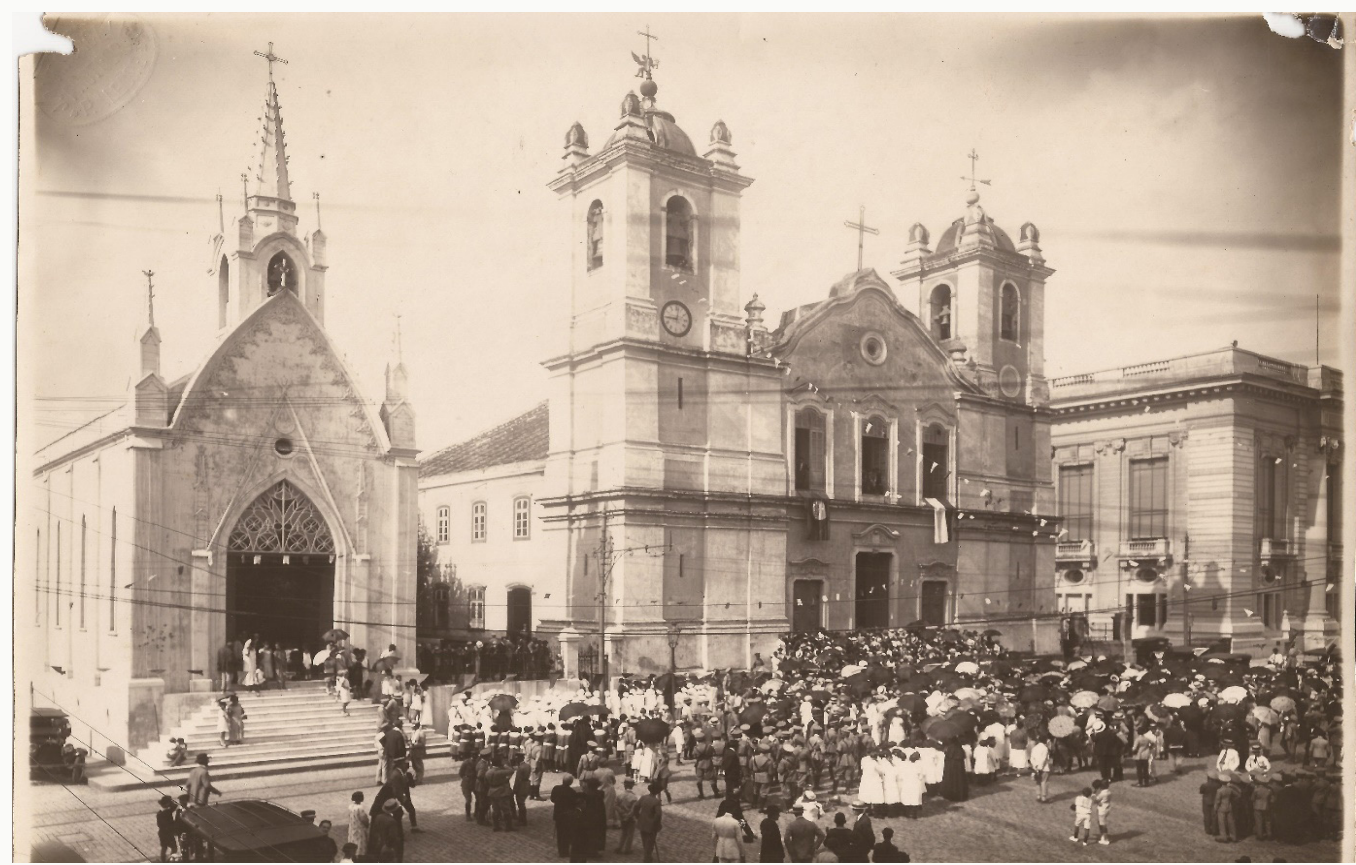

Fonte: Arquivo Histórico da Cúria Metropolitana de Porto Alegre (AHCMPA).

Antes de discutir as questões em torno do cemitério preciso informar ao leitor das mudanças sofridas nessa paisagem ao longo do tempo. Como pode ser visto na figura 3, o espaço sepulcral era composto, de norte a sul, dos seguintes espaços: a igreja matriz colonial, as catacumbas ${ }^{5}$ e o cemitério. Quando o cemitério da matriz foi fechado em 1850, em função da

4 Em 17 de abril de 1805 foi emitida uma Ordem Régia determinando o fim do "gravíssimo dano" de se sepultarem os mortos no interior das igrejas da Capitania de São Pedro do Rio Grande do Sul. Essa Ordem foi tardiamente aplicada em Porto Alegre (que foi a primeira cidade da Capitania à aplicar a nova legislação funerária), visto que entre 1807 e 1811 não foram registrados enterramentos no interior da matriz. Entre 1812 e 1814 estes voltam a aparecer, somando-se 92 óbitos. Após 1815, até 1849, há apenas 18 enterramentos internos. Não localizei explicações na documentação para esses hiatos, mas há uma hipótese para o ano de 1815: nele ocorreu a primeira visita pastoral de um bispo à Porto Alegre, e é provável que o governo religioso tenha em fim aplicado a proibição dos sepultamentos internos para agradar a Dom Coutinho. Corrobora com essa hipótese o fato desses últimos 18 enterramentos serem bastante sui generis, com a presença de vários sepultamentos secundários de militares falecidos em batalhas e posteriormente trasladados para a matriz. Sendo exceções à regra, considero o ano de 1815 como o último para os enterramentos ad sanctos. Para uma análise mais detalhada desses casos, ver Meirellles (2016, p. 138-146). Sobre os referidos enterramentos sui generis, ver na mesma obra as p. 115-119.

5 Muito pouco se sabe sobre a existência e os usos dessas estruturas em Porto Alegre na primeira metade do século XIX. As catacumbas são citadas apenas dez vezes nos livros de óbitos, entre 1806 e 1816, e não localizei nenhuma documentação informando do porquê de terem vida útil tão curta. 
proibição de sepultamentos dentro das igrejas e da área urbana, esse espaço ficou abandonado até 1865, quando o segundo bispo do Rio Grande do Sul, Dom Sebastião Dias Laranjeira iniciou ali a construção do Seminário Episcopal Madre de Deus. O prédio, onde também foi instalada a Cúria Metropolitana, foi inaugurado para as aulas em 1879, mas só concluído em 1888 . 0 Seminário funcionou no local até 1913, quando foi transferido para a cidade de São Leopoldo. A partir de então, a Cúria Metropolitana funcionou no edifício, até hoje, e desde 1946 abriga também a residência arquiepiscopal (para melhor localização, ver Figura 4). ${ }^{6}$

Figura 3: Detalhe da "Planta da cidade de Porto Alegre", de 1844

O no 1 representa a Igreja Matriz, o n 5 o cemitério e o nำ 7 as catacumbas.

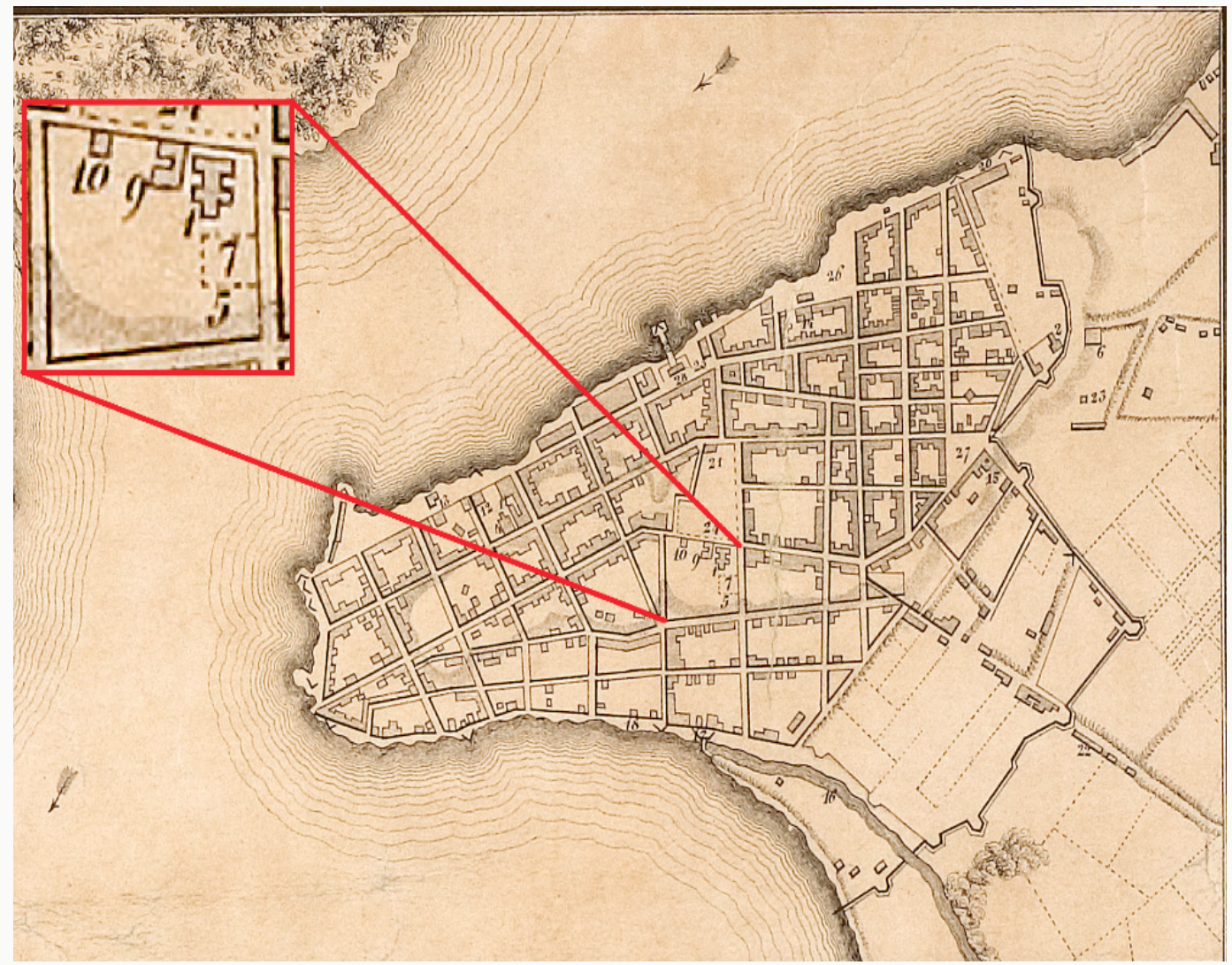

Fonte: IHGRS, 2005

6 Para visualizar o atual prédio da Cúria Metropolitana, acesse o link da imagem em 360ㅇ, disponível em: $<\underline{\text { http:// }}$ www. arquidiocesepoa.org.br/curia?catego=18exibir=4198>. Acesso em: 15/11/2016. 
Figura 4: Visão aérea atual do quarteirão formado pelos edifícios do Palácio do Governo, Catedral e Cúria Metropolitana

Enquanto o Palácio do Governo (no centro, acima) permanece no mesmo edifício apresentado na figura 3, o plano da nova Catedral é muito maior que a igreja antiga, comparando-se também com a planta apresentada na figura 2. Acredito que a igreja antiga iria, no máximo, até o início da cúpula da Catedral, em sentido sul. 0 quadrilátero visível na imagem se refere ao claustro do Seminário Episcopal, e se configura na área que recebeu as intervenções urante as escavações. Sob ele, estão os remanescentes do antigo cemitério.

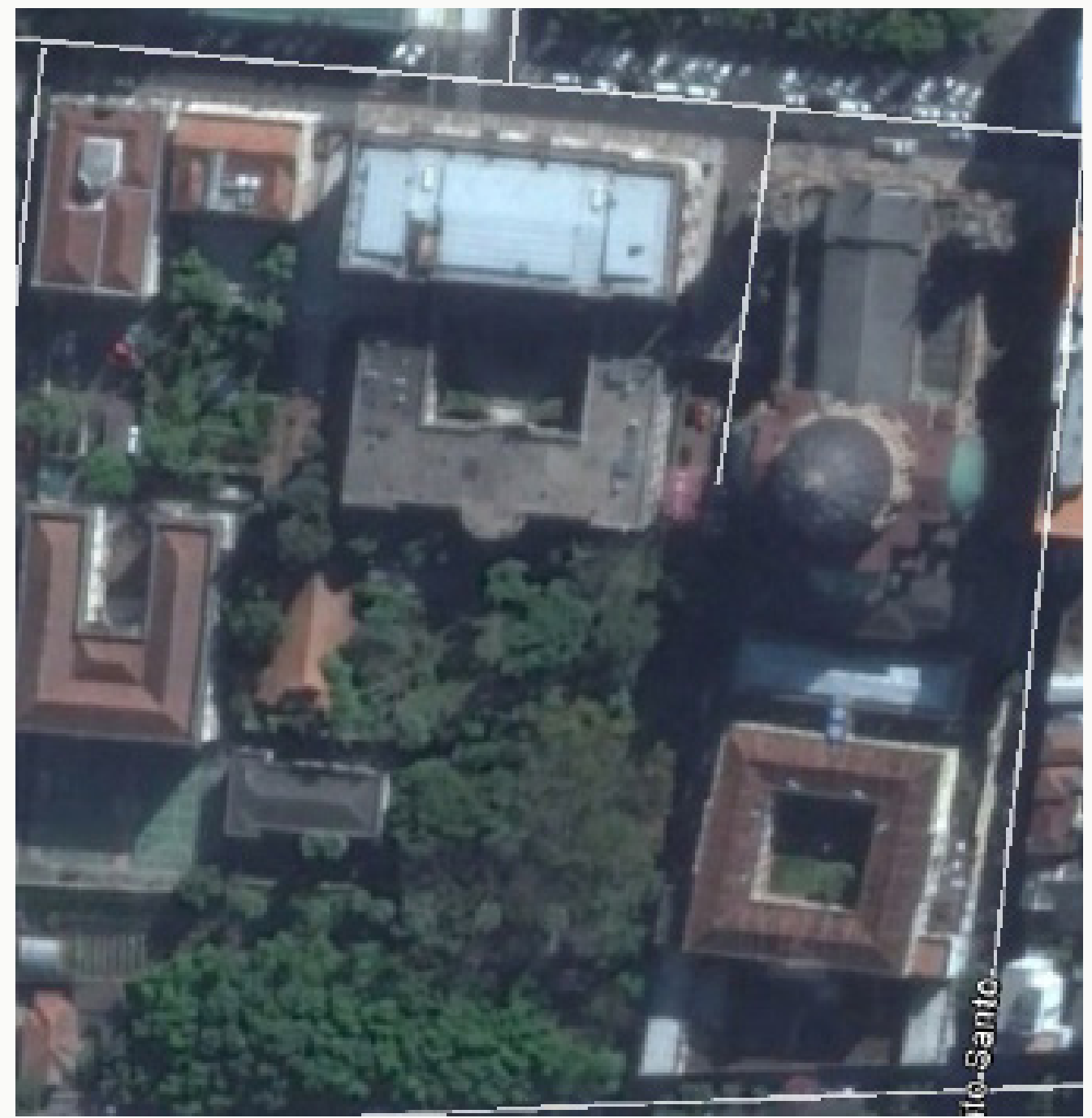

Fonte: Google Earth. Coordenadas:3002'03.58"S 5113'50.77"O. Data da imagem: 23/08/2016

A igreja matriz foi elevada à catedral, com a criação da Diocese de São Pedro, em 1848 pelo papa Pio IX. Com o passar do tempo foi se tornando cada vez mais exígua, fato agravado pela criação da arquidiocese em 1910, por Pio X. Esse fato deu início aos planos de demolição da antiga igreja, levados à cabo a partir de 1920 (Cheuiche, 2012). Para evitar a interrupção do culto, primeiro demoliu-se a sacristia e a nave-mor da antiga matriz, deslocando-se o altarmor para o arco-cruzeiro (ver figuras 5 e 6). No espaço vago onde anteriormente também eram localizadas as catacumbas e, posteriormente, o pátio do Seminário Episcopal, começou 
a ser erguida a cripta da nova Catedral. A missa de Ano Novo em 1928 seria realizada já na cripta quase concluída, ${ }^{7}$ para onde os corpos dos bispos seriam solenemente transladados, ${ }^{8}$ seguidos do altar-mor e altares secundários, tornando o local apto para o culto. ${ }^{9} \mathrm{~A}$ partir de então, o resto da Matriz antiga seria demolido. No entanto, a futura Catedral demoraria muitos anos ainda para ser concluída, devido a monumentalidade da obra e aos custos necessários para a mesma. A inauguração oficial só se daria na década de 1980, quando se finalizaram os afrescos em seu frontispício.

Figura 5: Fachada da igreja matriz na fase final de sua demolição, década 1920

Muito propagandeada nos jornais da época, a demolição do velho templo colonial foi alardeada pelo Arquiepiscopado como um dos primeiros símbolos da chegada do "progresso" em Porto Alegre. Desconheço ter havido na época algum tipo de resistência mais contundente por parte dos "conservadores" pela preservação do templo. Com a sua destruição, desapareciam de modo permanente os últimos elos com o antigo cemitério, já quase definitivamente "sepultado" com a construção do Seminário Episcopal no século anterior.

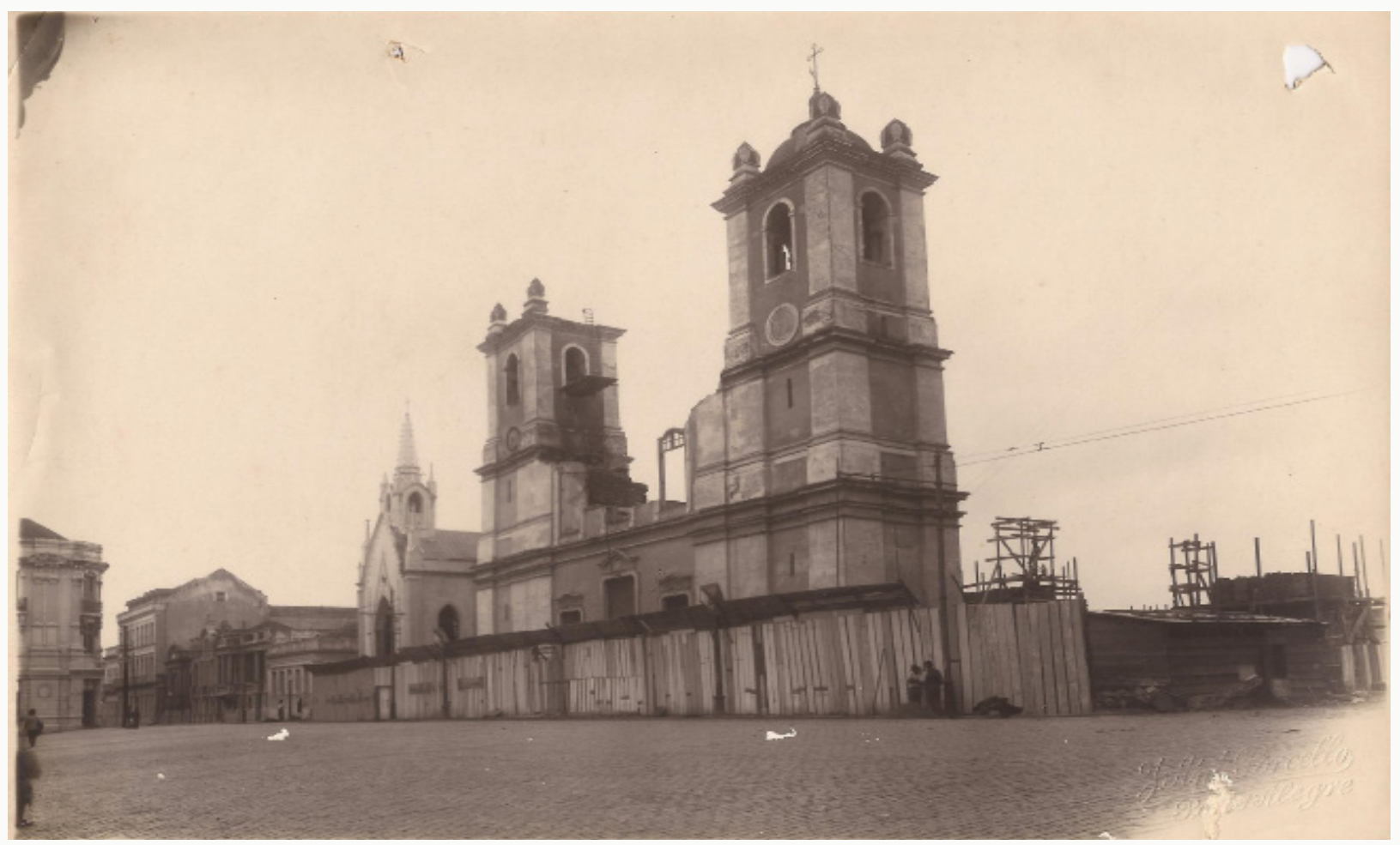

Fonte: AHCMPA.

7 Hemeroteca Digital da Biblioteca Nacional (doravante HDBN). A Federação, Porto Alegre, p. 3, 21 jan. 1928.

8 HDBN, A Federação, Porto Alegre, p. 3, 20 mar. 1928.

9 HDBN, A Federação, Porto Alegre, p. 5, 22 mar. 1928. 
Figura 6: Fundos da igreja matriz após a demolição da nave e translado do altar-mor para o arcocruzeiro (percebe-se a cicatriz na alvenaria), c.1920

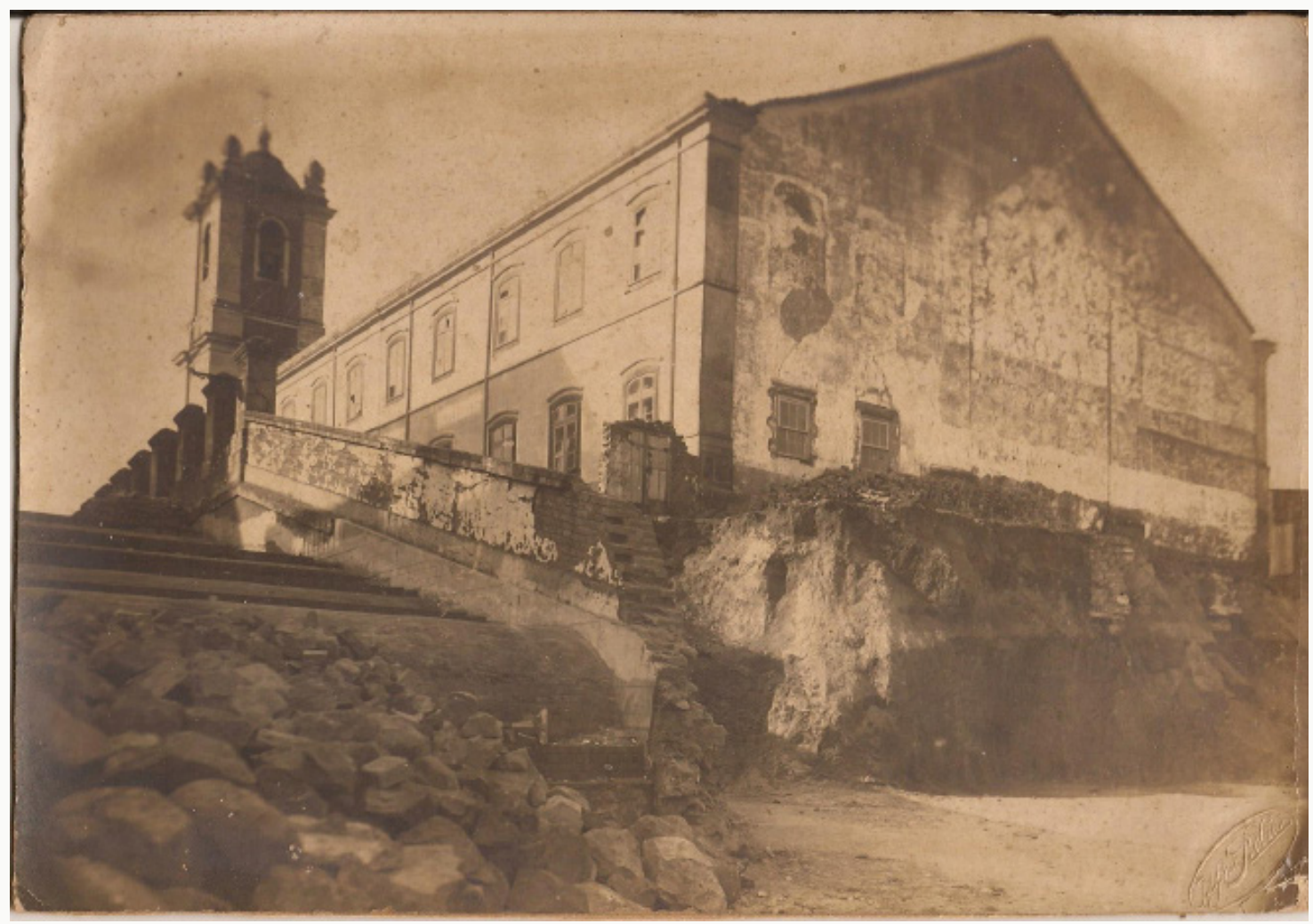

Fonte: AHCMPA

Importante salientar que a destruição da igreja colonial afetou profundamente o cotidiano da cidade. Apesar de ser pequena para a população - que em 1916 contava com cerca de 178.000 habitantes -, e considerada por alguns como simples demais para sede arquiepiscopal, justificando-se assim a sua substituição por um templo mais grandioso, aquele fora o principal local de culto da região desde o final do século XVIII e o local de descanso de mais de 1.700 cadáveres sepultados entre 1772 e $1849 .{ }^{10} \mathrm{O}$ relato de Achylles Porto Alegre, escritor que vivenciou a demolição da igreja, é contundente nesse sentido:

Um dia destes, fazendo o meu cotidiano giro matinal pela minha querida cidade, achei-me, de repente, na tradicional praça da Matriz, e logo

10 Embora o cemitério da matriz tenha funcionado até abril de 1850, os enterramentos no interior do edifício só se deram até 1849. Quando me refiro aos 1,700 cadáveres, esses são o somatório apenas dos enterrados dentro da igreja, visto que os sepultados no lado de fora ultrapassam a casa dos 20 mil. 
chamaram minha atenção grandes carroçadas de entulho que saiam dos fundos de nossa antiga catedral. [...] Ali, naquele templo augusto, viviam pelo menos cinquenta anos de minha existência, e eu via-o agora atacado e ferido pela picareta inconsciente do operário rústico, que nada conhece da vida da cidade antiga! E via, arrancados àquela terra santa, e que fora cemitério, a enxadadas brutais, as ossadas de muitos dos nossos antepassados, que eram dali expulsos, como uma espécie nova e singular de despejos, - como inquilinos que não pagam aluguéis de casa... [...] Como eu, a maior parte da população da cidade há de sentir o desaparecimento da nossa velha igreja, porque não há um habitante da capital que não tenha ali uma relíquia. São mais de cento e cinquenta anos da crônica da cidade e da vida de nossos avós que são lançados em terra, feitos destroços, transformados em poeira. (Porto Alegre, 1921, p. 77-80).

Enquanto a igreja da Madre de Deus foi alvo de diversas análises, principalmente na década de 1940 quando se comemorou o primeiro bicentenário da cidade, ${ }^{11}$ o seu cemitério ou adro - em pesquisas de caráter científico com uso de fontes primárias e análise detalhada na tese de Mara do Nascimento (2006) e na minha dissertação de mestrado (Meirelles, 2016). No seu trabalho, Nascimento o descreveu do seguinte modo:

O adro era um espaço localizado na parte exterior da igreja Matriz. É bem provável que ficasse atrás do edifício religioso, mas nada impede que também pudesse estender-se para as laterais e até mesmo nos terrenos à frente deste. [...] A sepultura a céu aberto esteve, no Ocidente, associada ao abandono ou desleixo dos funerais, ou como destinada àqueles mortos que não seriam recordados pela memória dos vivos. [...] Em Porto Alegre, após o ano de 1779 [...] o pároco passou a registrar para o local de sepultamento de escravos e livres de diferentes segmentos sociais somente o termo cemitério (Nascimento, 2006, p. 228-229).

Percebe-se que, para a autora, o cemitério seria um local de aspecto negativo, com sepulturas desleixadas, sem demarcações, reservada para os elementos mais baixos da sociedade. Esse tipo de tratamento ecoa tanto em análises de pesquisadores estrangeiros quanto brasileiros. Para Jacqueline Thibaut-Payen, "o ideal para os homens do período era ser sepultado nas igrejas, sendo que em algumas paróquias nem havia cemitério" (Thibaut-Payen, 1977, p. 17). ${ }^{12}$ O mesmo é dito por Phillippe Ariès (2014, p. 110-119). No contexto brasileiro, os historiadores são unânimes: ser enterrado em um cemitério era um "grande infortúnio", para José Reis (2009, p. 192-193), uma vez que "os templos são o cemitério do cristão", conforme Luiz Edmundo afirmou para o Rio de Janeiro (Rodrigues, 1997, p. 70-73). De acordo com Júlio Pereira, o único cemitério do Rio de Janeiro até 1722 era o da Misericórdia, conhecido por

11 Porto Alegre celebrou duas vezes os seus 200 anos de fundação, anomalia resultada de uma divergência historiográfica. Para um relato do caso ver, entre outros, Macedo (2004).

12 "L'idel, pour les hommes de cette époque, demeure l'inhumation dans l'église, à tel point que certains paroisses n'ont aucun cimetière". Traduzido por Pedro Meirelles. 
suas valas comuns e seu desleixo para com os cadáveres, razão pela qual escravos e libertos procuravam se filiar a irmandades negras, garantindo um funeral decente (Pereira, 2014).

Em Porto Alegre, pelo que temos conhecimento até o momento, os únicos a tratarem o cemitério com caracteres negativos são os vereadores interessados em fechá-lo, como podemos constatar nesta fala do vereador Ferreira à Câmara, em 1837:

\begin{abstract}
Constando que no Cemitério da Matriz desta cidade se não tem adotado regulamento algum, não só respeito á profundidade que devem ter as sepulturas, e espaço que deve medir de umas às outras; como a falta de um sinal, ou inscrição que denote o dia, mês e ano, em que o defunto ali foi sepultado, para não se abrir, se não passados pelo menos dois anos, sucedendo de um tal desleixo a terem-se aberto sepulturas, onde se encontram ainda cadáveres num tal estado de podridão; e com ainda a bem da salubridade pública que se faça desaparecer o quanto antes estes, e outros escandalosos abusos, que se observam no mencionado

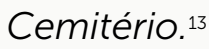

Igual tom seria usado em um relatório de 1846 do Presidente da Província, Conde de Caxias, que qualificaria o cemitério como "escândalo" e "foco de miasmas":

Nem mais impróprio podia ser o lugar [do cemitério], quase no centro da cidade, e por detrás da principal igreja, aberto por todos os lados, expostas as sepulturas aos olhos de todos, e servindo esse campo de ruínas de pasto, e refúgio a quantos animais [que] por ali vagavam em despeito das posturas da Câmara. ${ }^{14}$ E quantas vezes não jaziam à porta da sacristia fechada, cadáveres de escravos mal amortalhados, e foçados pelos cães errantes. Espetáculo de repugnante desmazelo, e já não de horror, que extingue na alma o sagrado respeito aos mortos, e que tanto, como à vista, ofende a moral e os costumes. Não menos danoso era à salubridade pública este tão pequeno cemitério, mas tão apinhado de cadáveres, cuja exalação, tão sensivel ao olfato em dias calorosos, era quase que suficiente para pejar 0 ar de partículas deletérias. ${ }^{15}$

13 ARQUIVO HISTÓRICO DE PORTO ALEGRE MOYSÉS VELLINHO (doravante AHPAMV). Atas de Vereança (18351839), vol. 12, fl. 168v, sessão de 1ำ de agosto de 1837. Grafia atualizada.

14 Há, nesse relato, uma retórica de convencimento muito grande, pois se trata do discurso de um militar que veio para o sul para pôr fim à Revolução Farroupilha e, ao mesmo tempo, resolver outros assuntos pendentes, como a criação do cemitério, cujas discussões já se arrastavam na Câmara desde o princípio do século. O que desejo afirmar é que, embora Caxias esteja falando de um cemitério específico, se utiliza de figuras de linguagem e lugares-comuns nos textos higienistas da época. A menção aos animais que pastavam no cemitério, por exemplo, é feita também em um discurso de uma autoridade baiana da década de 1830, citado por José Reis (2009, p. 260). Assim, alguns dos pontos do discurso podem não ser "originais" para Porto Alegre, como o caso do cemitério aberto. Fontes da época, como as atas da Câmara, demonstram que o mesmo era murado. AHPAMV, Atas de Vereança (1830-1832), vol. 10, fl. 92-92v, sessão de 14 de abril de 1831.

15 CENTER FOR RESEARCH LIBRARY. BRAZILIAN GOVERNMENT DOCUMENTS (CRL/BGD), Relatorio com que abrio a primeira sessão ordinária da segunda legislatura da província de S. Pedro do Rio Grande do Sul no 1.0 de março de 1846, o exm. Sr. conde de Caxias, presidente da mesma província. Porto Alegre: Typ. de I. J. Lopes, 1846, p. 19-20. Disponível em: http://www-apps.crl.edu/brazil/provincial/rio_grande_do_sul. Acesso em 06/10/2016. 
Quando se planejou o procedimento a ser tomado nas escavações arqueológicas, as informações existentes eram as mencionadas acima (com exceção para os dados sobre os enterramentos ad sanctos). O que esperávamos encontrar no subsolo da Cúria Metropolitana (erguida sobre o cemitério da matriz) eram, nesse sentido, ossos bastante dispersos oriundos dessas sepulturas consideradas mal distribuídas e constantemente perturbadas. Supúnhamos, também, encontrar poucos sepultamentos preservados, dado o grande manejo que o espaço sofreu com a construção do Seminário e a destruição da igreja. O encontrado, porém, superou as nossas expectativas: o cemitério escavado, apesar de ter sofrido diversas intervenções em seu subsolo, encontrava-se bastante preservado, com sepulturas intactas e com acompanhamento funerário junto às ossadas. É a experiência que tive no processo de escavação deste espaço que passo a relatar abaixo.

\section{O projeto de restauro}

O projeto de restauro da Cúria Metropolitana (atual função do prédio do antigo Seminário Episcopal, que fora erguido sobre parte do antigo cemitério da matriz ${ }^{16}$ foi desenvolvido em 2010. O conjunto arquitetônico da Catedral e da Cúria, com área total de $4.489,65 \mathrm{~m}^{2}$, foi tombado pelo município de Porto Alegre em 31 de março de 2009 (tombamento municipal no 68, registrado na página 016 do Livro Tombo), fazendo parte ainda do entorno do conjunto arquitetônico da Praça da Matriz, tombado pelo Instituto do Patrimônio Histórico e Artístico Nacional (IPHAN). O que reforça ainda mais a sua relevância cultural. ${ }^{17}$

Sendo o imóvel tombado e não podendo ser alterado em sua forma original externa, todas as transformações que seriam feitas - como a modernização da rede elétrica, a instalação de calhas anti-infiltração e a construção de uma central elétrica e do estacionamento - foram planejadas para o subsolo a ser escavado (ver Figura 7). O responsável pela empresa de restauro Arquim Construções e Restauros Ltda., o Sr. Edegar Bittencourt da Luz, solicitou a contratação de uma equipe de arqueologia posto que já havia trabalhado em prédios históricos antes. Após licitação, foi contratada a arqueóloga Angela Maria Cappelletti, que já havia trabalhado nas escavações e restauro da Igreja Nossa Senhora das Dores, também em Porto Alegre, no âmbito do programa Monumenta - Centros Históricos (ao qual o restauro da Cúria também estava vinculado).

16 Como não há imagens cartográficas que apresentem bem o antigo cemitério, existe a dificuldade de se definir qual era a sua área total e até onde se estendia. Com base em "migalhas" espalhadas por documentações primárias de várias origens, sugiro que o mesmo não ia até a atual rua Fernando Machado, que se configura como a fachada sul do prédio do Seminário Episcopal, e pode ser vista na imagem 4 acima. Creio que a área das sepulturas iria até onde está o quadrilátero do claustro do Seminário, visível na mesma imagem. Assim, é correto dizer que este prédio está assentado sobre a extinta necrópole. Em minha dissertação discuto o porquê desse local ter sido escolhido para a ereção do edifício e suas implicações com o projeto reformador proposto pelos primeiros bispos do Rio Grande do Sul. Cf. Meirelles, 2016.

17 CONSELHO ESTADUAL DE CULTURA DO ESTADO DO RIO GRANDE DO SUL. Relatório no 0491-12: Restauração da Cúria Metropolitana de Porto Alegre e Seus Anexos - 2012. Disponível em: http://www.conselhodeculturars. com.br/projetos_conselho.asp. Acesso em 06/10/2016. 
O primeiro projeto arqueológico previu o acompanhamento da retirada do contra piso e o monitoramento da escavação por parte dos operários da Arquium de três contextos principais: uma grande área ao sul, junto à entrada original do prédio do antigo Seminário, na qual seria feito o estacionamento subterrâneo; uma área menor, à leste, onde seria construída uma subestação de energia; e uma vala de drenagem ao redor de todo o prédio. No andamento dos trabalhos, novas áreas não planejadas foram surgindo, fazendo com que esta previsão inicial se alterasse.

Figura 7: Projeto de restauro da Cúria Metropolitana, com as áreas a serem escavadas assinaladas em cor mais escura

A área mais escura à esquerda (sul) se configura em uma escadaria monumental que daria acesso ao antigo Seminário (1879-1913). No quadrilátero (antigo claustro do Seminário) se encontram, atualmente, no primeiro andar (térreo) as funções administrativas da Arquidiocese, e no segundo andar, a área íntima, com dormitórios e capela privada. No subsolo fica a área de serviço, com lavanderia, vestiário dos funcionários, e depósitos. Não está visível na planta, pois não foi abarcada pelo restauro, a área do batistério, casa paroquial e arquivo histórico, que ficaria à direita na imagem (norte), e pode ser vista na imagem aérea atual apresentada acima.

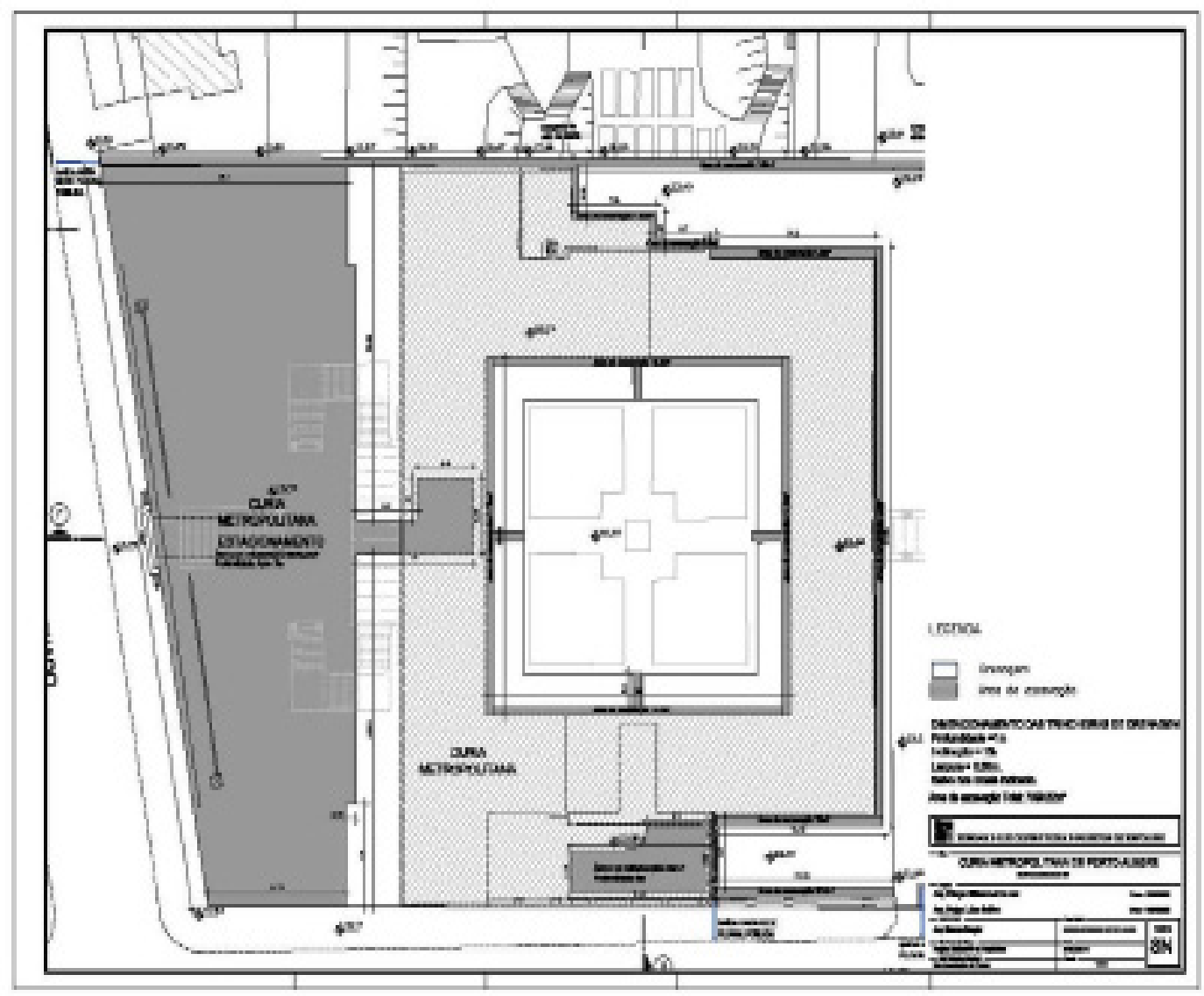

Fonte: Arquium Construção e Restauro Ltda., 2010. 


\section{As escavações}

Como é de praxe nas intervenções arqueológicas urbanas atuais, quase sempre vinculadas a empreendimentos, o trabalho do arqueólogo só é feito naqueles locais que serão afetados pela obra. A malha de escavação só é expandida para além do planejado pelo empreendimento apenas em último caso. Procura-se, sempre, deixar o que quer que esteja no subsolo preservado, desviando a obra e só escavando e removendo os remanescentes materiais em caso de destruição iminente dos vestígios.

No caso da Cúria, a equipe de arqueologia foi contratada após o começo dos trabalhos por parte da Arquium, em 2011. Ao chegarmos ao local, percebemos que em 2010 já havia sido escavado um poço-teste na lateral do prédio onde seria feita a subestação de energia, para que se tivesse uma noção de até onde iam as fundações do muro ao redor do prédio. Assim, quando iniciamos o trabalho, nos deparamos com três grandes montes de terra, depositados ao redor deste poço. Neles, centenas de fragmentos ósseos, tanto humanos como animais, além de outros tipos de materiais como cacos de louça e vidro, metais como pregos e botões, etc. Todo esse material foi recolhido, mas como não estava associado a nenhum contexto específico, não pode ser estudado a fundo.

Verificou-se, entretanto, a presença de grandes quantidades de sedimentos exógenos ao local: devido à grande inclinação do terreno (como pode ser visto na figura 1 acima), foram trazidas várias levas de aterro de outras áreas da cidade para a construção do Seminário Episcopal, entre 1865 e 1888. Nos perfis estratigráficos ${ }^{18}$ do poço-teste, verificou-se que quanto mais ao sul, ou seja, em direção ao caimento da ladeira, mais camadas de aterro eram verificadas. Duas outras informações foram descobertas: a primeira, indicada pela presença de ossos humanos junto às camadas de aterro, sugeria que parte da terra usada no nivelamento do terreno veio do próprio cemitério; a segunda era a de que, abaixo de tudo isso ainda pareciam haver sepulturas preservadas.

A partir dessa análise foi elaborada a seguinte estratégia: os operários seriam responsáveis pela retirada das camadas de aterro nas áreas em questão. Usariam pás, enxadas e picaretas para remover o sedimento sob a supervisão de um membro da equipe de arqueologia e sempre que algum vestígio arqueológico - ossos humanos ou outros materiais - surgisse, as ferramentas pesadas seriam abandonadas em prol de instrumentos mais delicados. Este trabalho prosseguiria até que se atingisse a superfície do cemitério quando, a partir de então, todo o trabalho seria executado pelos arqueólogos.

No lado de dentro do prédio da Cúria, em uma sala na fachada oeste (sala C13), foi aberto um buraco para instalação de um elevador de carga conectando a cozinha à lavanderia. Fomos acompanhar o trabalho dos operários desde a remoção do contrapiso. Logo abaixo do piso mais recente, instalado provavelmente na década de 1970, foi encontrado um aterro feito com caliça e fragmentos de ladrilhos hidráulicos do século XIX, confirmando materialmente que o interior do prédio já havia passado por uma reforma anterior. Abaixo disso, sucederam-

18 Nome dado à "parede de terra" existente nos cortes do terreno, que demonstram a disposição das camadas de sedimento. Camadas mais profundas, na maioria dos casos, são sedimentos mais antigos. 
se várias camadas de aterro, muitas das quais contendo material arqueológico e fragmentos de ossos humanos e de animais. Os ossos humanos, aparentemente mais frágeis ou mais antigos, encontraram-se majoritariamente muito delicados, farelentos, se desmanchando ao toque. O terreno original no qual se assenta a Cúria é caracterizado como uma colina de granito em decomposição, muito argiloso, resultando em um solo pouco permeável. Os ossos, já danificados pela constante manipulação, acabaram prensados entre uma sucessão de camadas úmidas e pouco permeáveis, acabando por se decompor com a umidade.

Figura 8: Sepultura 1, sala C13

Restos ósseos de dois indivíduos adultos, sexo não identificado. À esquerda, o remanescente de uma pelve com um fêmur ainda presente, perturbados pela construção da parede; ao centro, um par de pernas; e à direita, um crânio virado de lado, não relacionado à nenhuma sepultura. Estão bem visíveis nesta imagem os danos causados aos enterramentos pela construção das fundações do Seminário. 
De qualquer maneira, ao se atingir a camada original do cemitério anexo à antiga igreja matriz - caracterizada por um sedimento mais escuro e com uma consistência mais terrosa, rico em matéria orgânica e bastante diferente daquele dos aterros -, encontramos duas sepulturas, uma que fora cortada ao meio pela construção das paredes externas do Seminário, em meados do século XIX, e outra intacta, com um esqueleto adulto inteiro, mas, infelizmente, totalmente decomposto (figura 8). No caso desta última, apenas o contorno dos ossos era visível no solo. O formato da sepultura era antropomórfico, indicando que fora escavada diretamente na terra e que, portanto, não havia o uso de caixões (Reis, 1991, p. 174-175). ${ }^{19}$ Nas laterais do corpo foram encontradas manchas esverdeadas, muito finas, resultantes da decomposição de alfinetes feitos com alguma liga de cobre (ver figura 9). Acreditamos, baseados na bibliografia sobre os enterramentos da época, que isto indique o uso de mortalhas presas com alfinetes.

Figura 9: Falange humana com presença de material metálico (cobre, com oxidação verde), possivelmente alfinete

Este exemplo foi um dos mais nítidos encontrados por apresentar ainda o material metálico aderido ao osso.

Foram encontrados alfinetes dispersos no solo escuro do cemitério, mas que poderiam ser das roupas ou adereços colocados junto ao cadáver. O apresentado na imagem, por estar junto às mãos do falecido, nos levou a crer que se tratava de alfinete para fechar a mortalha, aliado à evidência de que não se fazia uso de caixões e na bibliografia específica que acusa o uso desses materiais.

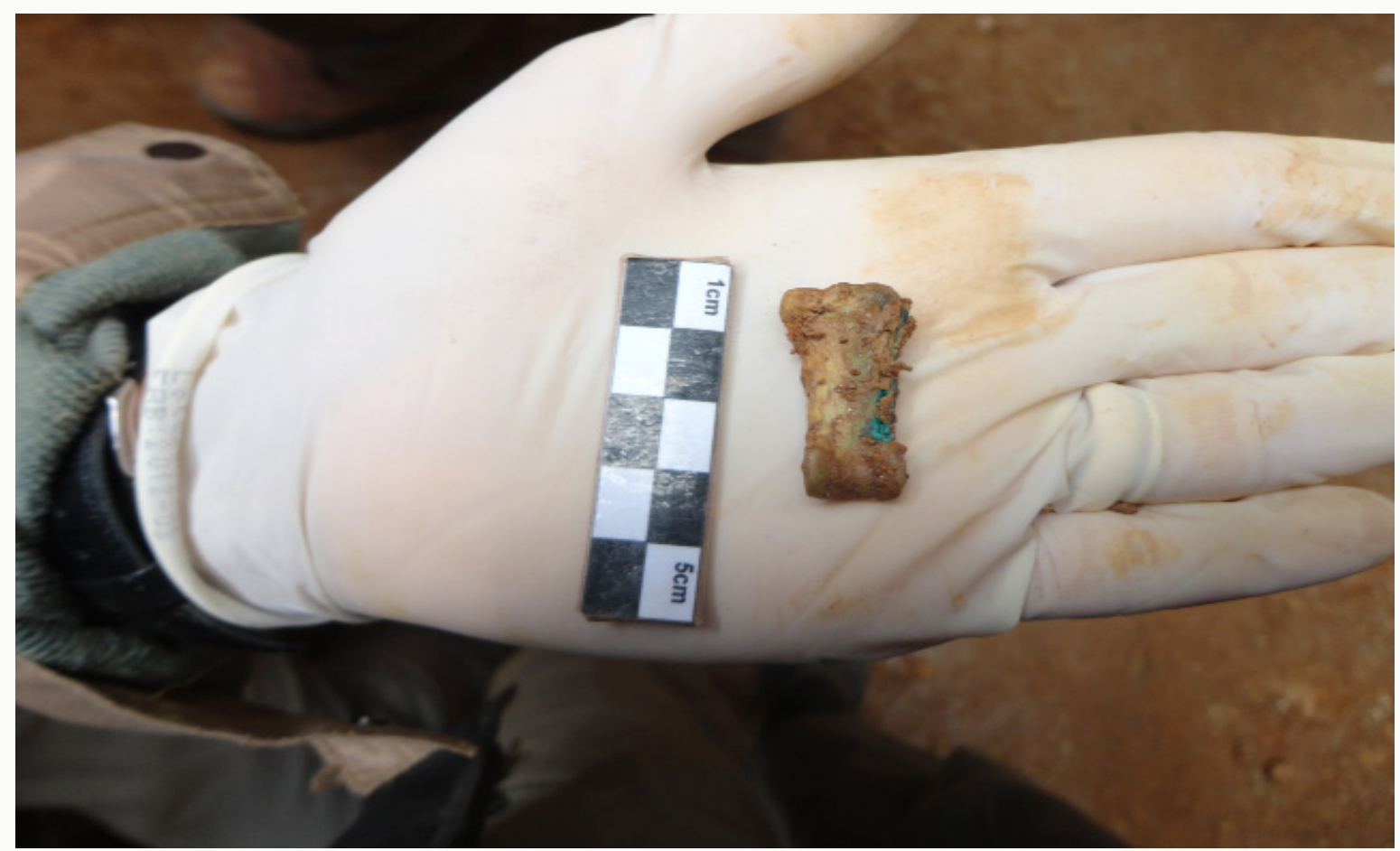

Fonte: Equipe de Arqueologia, 2012.

19 O uso de caixões para sepultamento foi disseminado a partir das recomendações de médicos durante os surtos epidêmicos a partir de meados do século XIX, a fim de evitar a contaminação dos vivos. (Rodrigues, 1997, p. 60-62) 
A área com maior número de descobertas se localizava no lado leste do terreno, entre o prédio da Cúria e o muro externo, próximo à rua Espírito Santo, onde anteriormente, de acordo com a cartografia de época, se localizava o cemitério da matriz. Denominada de "Área A" para fins de organização, foi dividida em quatro subáreas ( $A 1$ a $A 4$ ), sendo que $A 1$ resultava no poço-teste aberto pela equipe de restauro em 2010. A profundidade total do poço foi de seis metros e verificou-se que o mesmo não havia atingido a camada de solo escuro (figura 10), indicando que a superfície do cemitério estava bastante abaixo do piso moderno. Trabalhamos com ferramentas pesadas junto com os operários, tentando escavar em níveis de dez em dez centímetros para haver um controle maior; posteriormente, aumentamos para vinte centímetros. Toda a terra retirada foi peneirada para que se resgatasse qualquer fragmento de interesse que houvesse escapado aos olhos. A escavação foi feita de modo escalonado, sendo cada subárea rebaixada em um metro por vez, para impedir o desbarrancamento dos perfis.

Figura 10: Visão da Área A ao final da escavação

As sepulturas mais profundas foram abertas diretamente no granito em decomposição, que é um sedimento friável, mas bastante duro. O formato da cova não foi definido pela equipe de arqueologia, que só removeu o sedimento menos compacto que originalmente cobria o corpo. As saliências presentes na foto serviam de "divisórias" entre as covas, garantindo a individualidade de cada enterramento, mesmo quando estavam amontoados. A marca escura no perfil estratigráfico, na parede, demarca o grau de inclinação do cemitério, indicando grande declive.

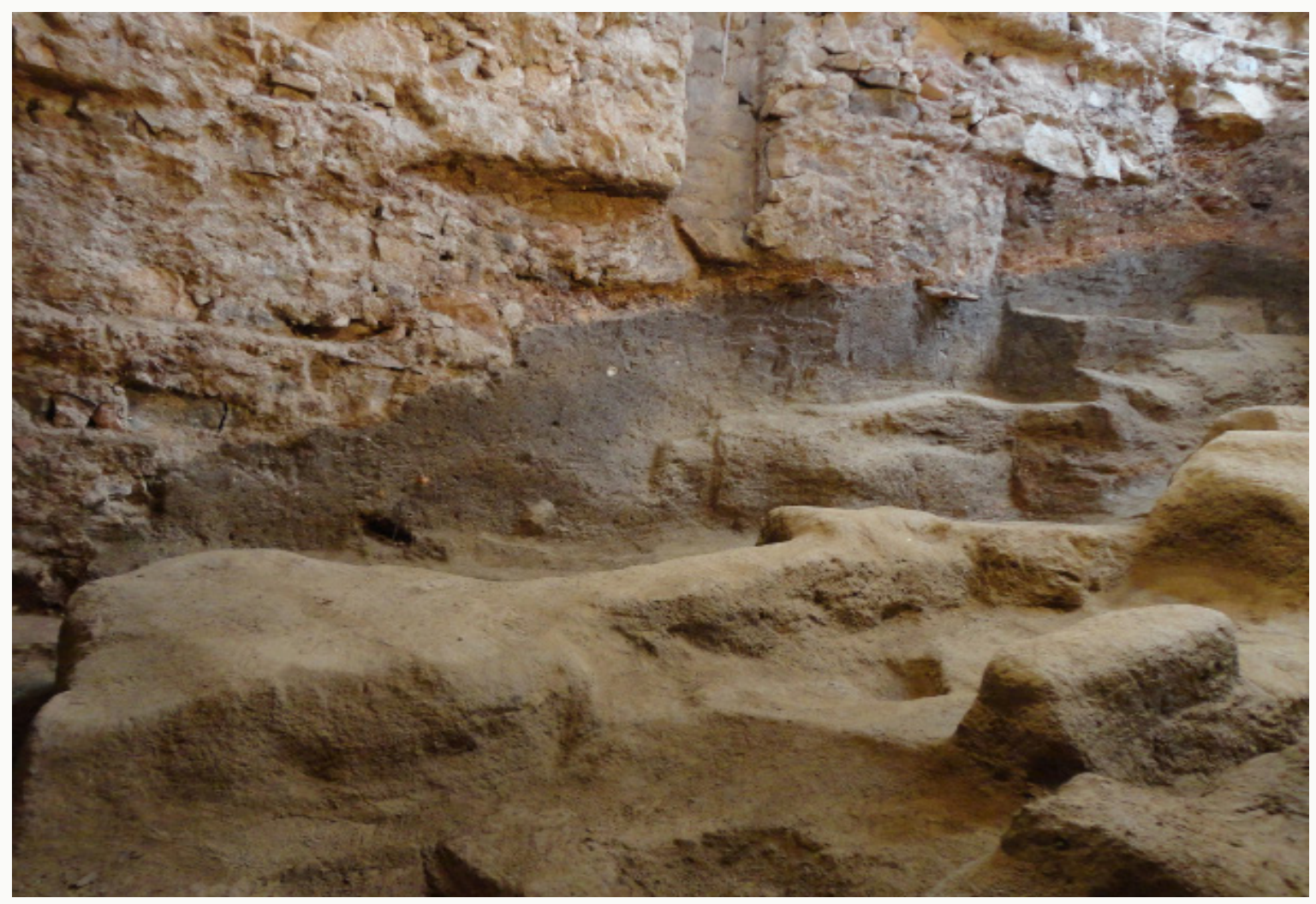

Fonte: Equipe de Arqueologia, 2012 
Em torno de 50 centímetros abaixo da superfície, no canto nordeste da subárea A4, surgiu um amontoado de fragmentos de ossos longos e crânios (figura 11). Como parecia haver mais ossos reunidos naquele local logo abaixo, escolhemos por preservar esse monte, ao invés de recolhermos diretamente, como estávamos fazendo com o restante do material encontrado. Para nossa surpresa, o monte seguiu aumentando, ao ponto de que quando atingimos a sua base, este tinha cerca de 1,30 metros de altura com mais de 2 metros de extensão. A análise do perfil estratigráfico demonstrou que o monte estava localizado sobre a camada do cemitério e era anterior aos aterros nos quais se encontrou materiais datados do final do século XIX, indicando que ele teria sido formado logo após o fechamento da necrópole em 1850 (ver figura 11).

Figura 11: Vista do monte de ossos da subárea A4, juntamente com o perfil estratigráfico norte

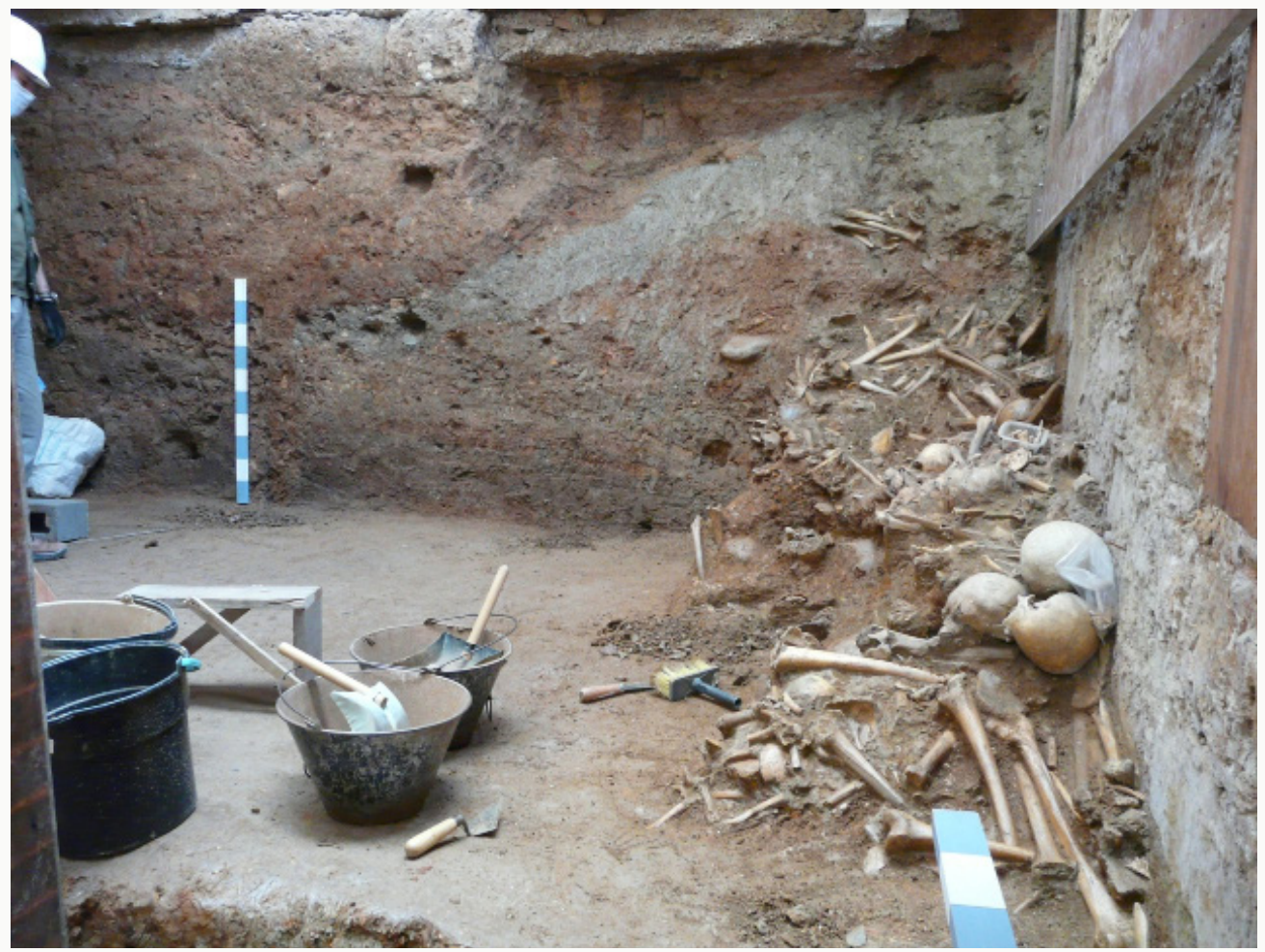

Fonte: Equipe de Arqueologia, 2012

Nesta concentração estavam depositados ossos de todos os tipos, embora houvesse grande quantidade de crânios (mais de 50, no total). O monte fora assentado diretamente sobre o solo escuro do cemitério, mostrando ser mais recente que este. No perfil da parede norte, são visíveis diversas camadas de aterro que se distribuem com a forma de uma "onda" caindo para a esquerda da imagem. No substrato marrom avermelhado, depositado juntamente com os ossos (e logo abaixo da camada mais cinzenta, bem visível na foto), foram encontrados fragmentos de louça datados do final do século XIX ou início do século XX. Todas essas informações levam à conclusão de que esta concentração foi formada durante uma das duas obras que rasgaram 
o solo da necrópole: a construção do Seminário ou a demolição da igreja matriz.

Contexto parecido foi encontrado ao sul da subárea A1. A divisa meridional do poçoteste aberto em 2010 era uma das paredes internas do Seminário construída entre 1865 e 1879 e que alterava a sua largura em torno de 8 metros abaixo do nível térreo do prédio, formando um "degrau" sobre o qual foram depositados, arrumados no sentido do comprimento, dezenas de ossos longos - úmeros, ulnas, rádios, fêmures, tíbias e fíbulas (figura 12).

Figura 12: Vista superior da subárea A1

Notar, no limite da área escavada, à direita, o amontoado de ossos longos. As paredes visíveis à direita e abaixo, na foto, formam as salas do subsolo do Seminário, enquanto aquela acima, o muro externo. A concentração de ossos, destacada na foto, provavelmente foi formada com material oriundo das sepulturas destruídas durante a construção dessas estruturas entre 1865 e 1879.

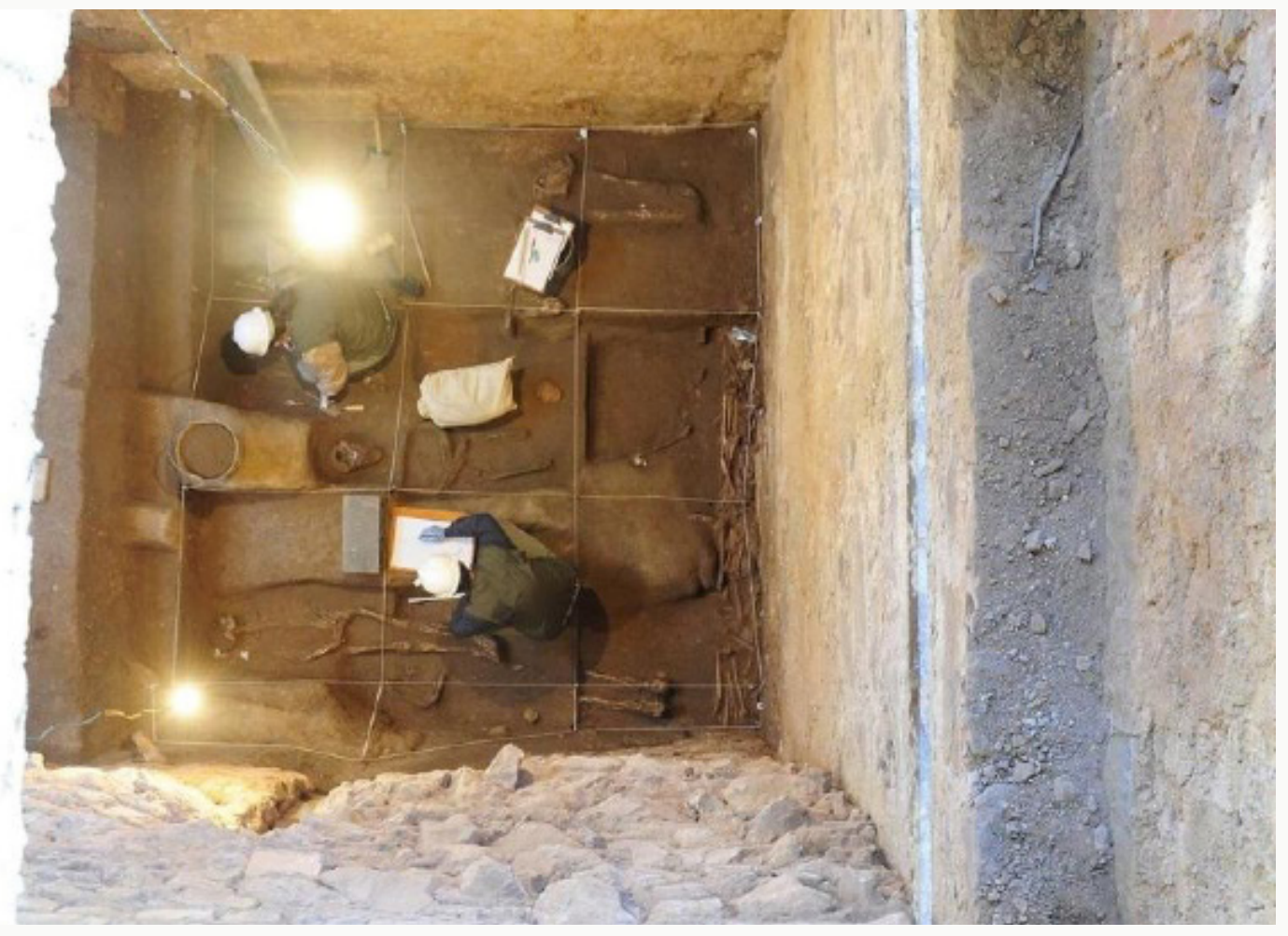

Fonte: Ricardo Duarte/Agencia RBS, 2012

Essas duas situações apontam que, diferentemente do que foi divulgado pela imprensa anticlerical na época das obras, parece ter havido, sim, um cuidado com os restos mortais encontrados na abertura das fundações do Seminário. ${ }^{20}$

20 O jornal liberal e contrário aos bispos ultramontanos A Reforma, assim noticiou em 1869: "Pessoas que nos merecem inteira fé, informam-nos que nos terrenos juntos ao Seminário em construção, encontram-se ossos humanos, que servem de divertimento aos rapazes que vão por ali vagar! Os nossos informantes viram não só caveiras e outros ossos, como o divertimento a que nos referimos. Só o Sr. Bispo que ali vai as tardes inspecionar suas obras, só os padres que o acompanham não tem olhos para verem aquela profanação! Levante-se o edifício do seminário, que importa os ossos humanos que lhe servem de alicerce e que junto a ele branqueiam? Os olhos clericais não os veem: a luz que os esclarece concentra-se em outros interesses que dizem respeito à... igreja. Se se tratasse de algum negócio jesuítico, de alguma questão ultramontana, de algum rendimento da secretaria do bispado, os olhos clericais estariam abertos. Mas, ossos humanos, os padres não veem! Que profanação!". MCSHJC, A Reforma, Porto Alegre, p. 3, 02/07/1869. Grafia atualizada. 
Ademais, nas subáreas A1, A2 e A3, uma vez alcançado o nível do cemitério, foram descobertas quase vinte sepulturas escavadas na rocha, sendo que nove delas ainda possuíam ossadas in situ (preservadas em seu local original): um esqueleto infantil, cinco adultos e outros três que não puderam ser identificados por só existirem as partes inferiores das pernas preservadas (na figura 13, um instante da escavação do esqueleto mais preservado encontrado). Novamente, as sepulturas tinham formato antropomórfico, o que junto com a ausência de fragmentos de madeira e pregos apontam para o não uso de caixões (figura 16). Uma fotografia em 360 da área das sepulturas, tirada pelo jornal Zero Hora, pode ser visto no seguinte endereço: <http://omarjunior.com/fotografia/projeto/escavacoes-na-curia-metropolitanade-porto-alegre/ $>.^{21}$

Figura 13: Autor evidenciando o enterramento 10, subárea A1

Análises antropométricas posteriores informaram se tratar de um indivíduo adolescente do sexo feminino com provável origem ou ascendência africana. Este foi o esqueleto mais intacto localizado nas escavações. Estavam ausentes só as porções inferiores das pernas, visto que uma parede do atual Seminário foi construída sobre a sepultura. Embora essa ossada ainda não tivesse sido descoberta quando a figura 12 foi registrada, é possível comparar essa à figura 16 para visualização da parede que decepou a porção inferior do cadáver.

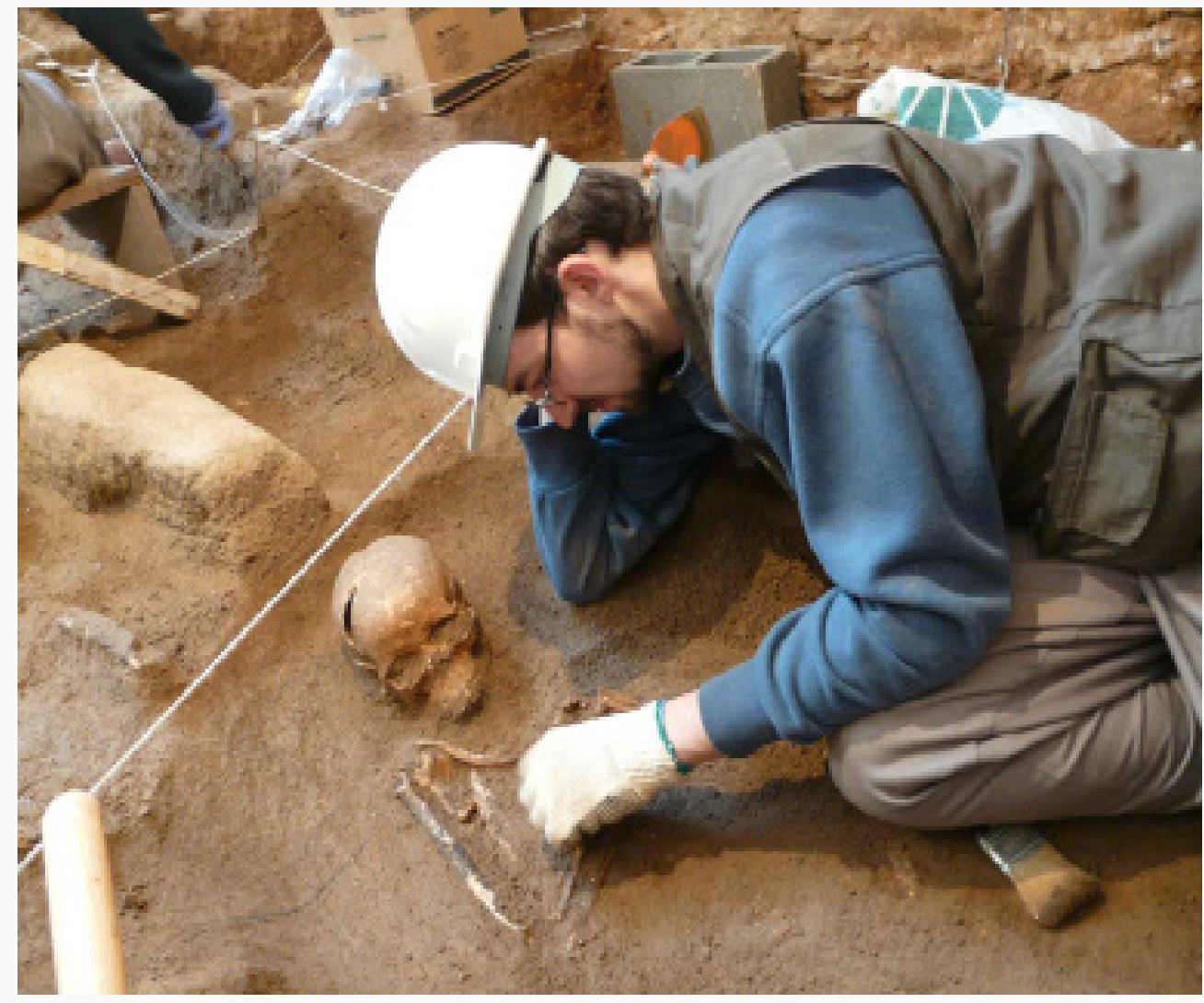

Fonte: Equipe de Arqueologia, 2012

21 Sugiro que se desconsidere a informação dada neste site de que o cemitério ficou 147 anos esquecido. A data informada por este autor se refere a 1865, ano no qual se iniciaram as obras para a construção do Seminário. O cemitério foi "resgatado" pela imprensa em épocas contemporâneas pela primeira vez em 1997, mas como na época nada foi feito, pode-se considerar 2012 como o ano de seu redescobrimento. Disponível em: http:// www.correiodopovo.com.br/Jornal/A102/N266/HTML/19OSSADA.htm. 
Alfinetes de liga de cobre foram achados junto às ossadas, bem como junto ao crânio de um bebê, pequenos elos de cobre que aparentavam formar um tipo de malha: é possível que fossem o forro de uma peruca de "anjinho" utilizada nos funerais infantis (figura 14) (Vailati, 2010, p. 143-144). Soltas no solo do cemitério e concentradas ao redor de duas ossadas, foram encontradas contas de colar feitas de vidro colorido, semelhantes às guias de santo modernas (figura 15). Um dos corpos associados às contas também vestia um crucifixo de metal, o que poderia indicar um sincretismo religioso. ${ }^{22}$ Ainda inexistem trabalhos sobre as práticas funerárias negras em Porto Alegre, sendo muito poucos os do Rio Grande do Sul, nenhum calcado em fontes arqueológicas. Desse modo, deixo aqui apenas a hipótese de que, havendo um armador negro em Porto Alegre no período, responsável por levar africanos e não-africanos para a sepultura, é possível que ocorresse práticas sincréticas.

Figura 14: Malha de pequenos anéis de cobre, bastante decompostos

Embora não fique claro na imagem, o que se apresenta acima é uma fina malha de anéis de cobre, muito pequenos e completamente decompostos, que foi encontrada, entre outros contextos, junto ao crânio de um bebê (que não estava associado à sepultura alguma). O osso do crânio estava manchado de verde, indicando a associação desse ao material. A bibliografia especializada faz menção à perucas de "anjinhos" que eram postas nos cadáveres dos inocentes, sendo possível que este material represente a estrutura de uma dessas perucas

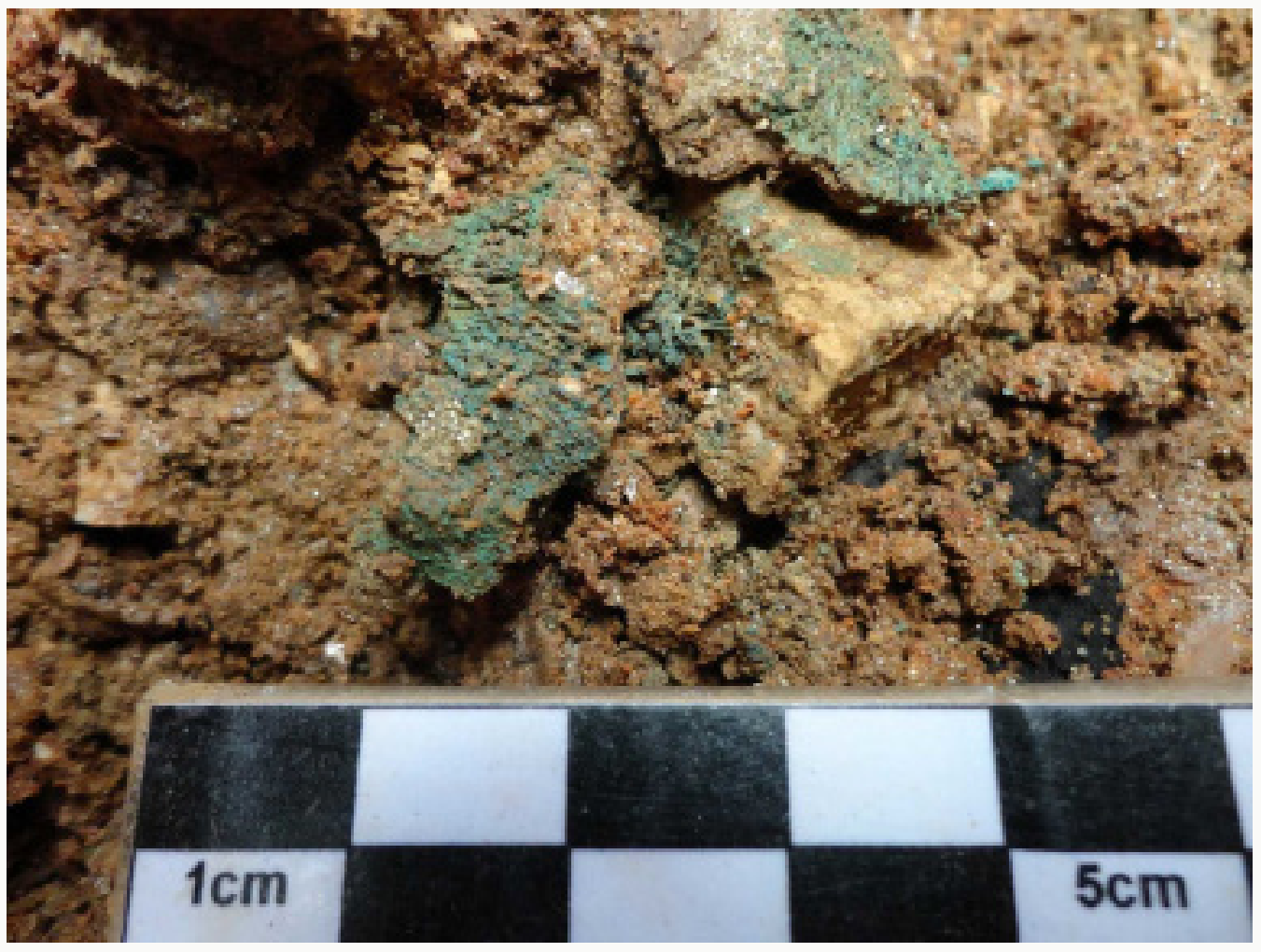

Fonte: Equipe de Arqueologia, 2012

22 Paulo Staudt Moreira, em artigo recente, apresentou o caso de Adão Miguel da Soledade, um preto liberto descrito pelo autor como "uma espécie de agenciador de serviços fúnebres, um especialista nos rituais religiosos da morte". Adão, falecido em 1856 (e, portanto, atuante durante a existência do cemitério), era uma referência na comunidade negra local, e em seu inventário deixou arrolados muitos bens que indicam o seu trato com a morte: caixões de diversos tamanhos, tecidos, peças de metal, flores, coroas, imagens de santos, artes sacras, etc. (Moreira, 2014). 
Figura 15: Contas de colar feitas de vidro colorido

Três exemplos de contas de colar em vidro colorido achadas junto aos ossos e no solo do cemitério. Essas contas, referendadas na bibliografia estrangeira como "slave beads" ou "trade beads" são bastante comuns em contextos arqueológicos relacionados com a escravidão africana, pois eram usadas como moeda de troca pelos europeus na África e valorizadas como vestimenta ritual. ${ }^{23}$

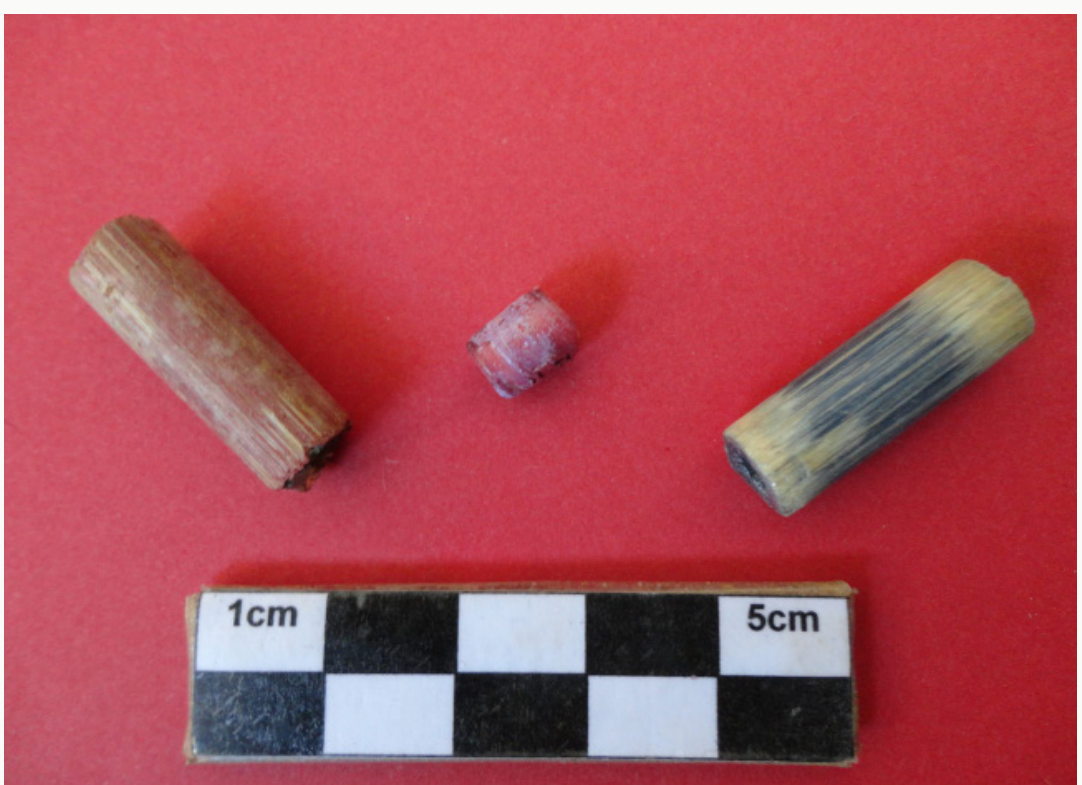

Fonte: Equipe de Arqueologia, 2012

O que chama atenção é que, como pode ser visto nas Figura 16 e 17, não havia de fato um ordenamento nas sepulturas: os corpos eram colocados uns sobre os outros, com apenas uma fina camada de terra entre eles. É possível ver que o esqueleto mais à esquerda, acima, está com a pelve apoiada sobre a cabeça da ossada logo abaixo. A grade de fios brancos disposta sobre a imagem delimita quadrados de cerca de um metro quadrado; percebe-se como ao menos dois corpos ocupam cada quadrante deste.

Figura 16: Vista superior das sepulturas na Área A

São visíveis na imagem quatro ossadas adultas de sexo não identificado, uma infantil (a lâmpada está posicionada logo acima do crânio dessa), uma adolescente, que é visível em maiores detalhes na figura 13, e o crânio de um bebê, mencionado no texto acima, e presente no quadrante inferior esquerdo da fotografia.

23 Embora não tenha localizado referências na bibliografia nacional sobre a descoberta dessas contas em cemitérios brasileiros com presença de enterramentos escravos, várias centenas desses objetos foram resgatados no Afrikan Burial Ground, um grande cemitério escravo descoberto em Manhattan, Nova lorque, na década de 1990. Disponível em: http://waistbeadsjel-jellisbyafyaa.weebly.com/tradeslave-beads.html. Acesso em 07/01/2017. 


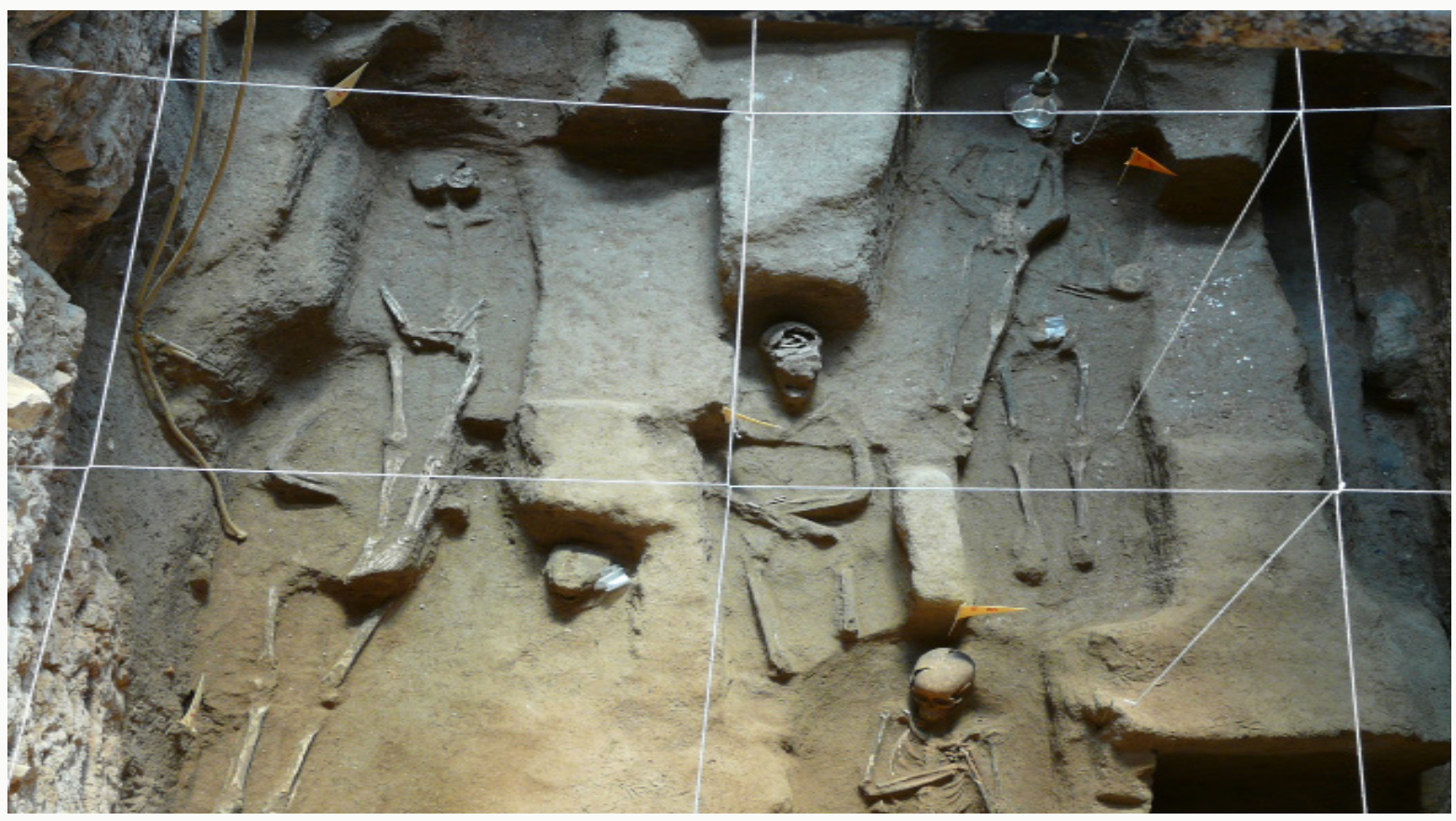

Fonte: Equipe de Arqueologia, 2012

Figura 17: Vista superior das sepulturas da Área A após a remoção das ossadas

Nesta imagem é visível a mesma área da foto anterior, porém sem as ossadas. Cada plaquinha demarca uma cova identificada durante a escavação, não necessariamente associada à um esqueleto. Importante destacar que só estão marcadas aqui as sepulturas mais profundas, escavadas diretamente na rocha em decomposição. Acima dessas existiram outras, abertas no solo friável.

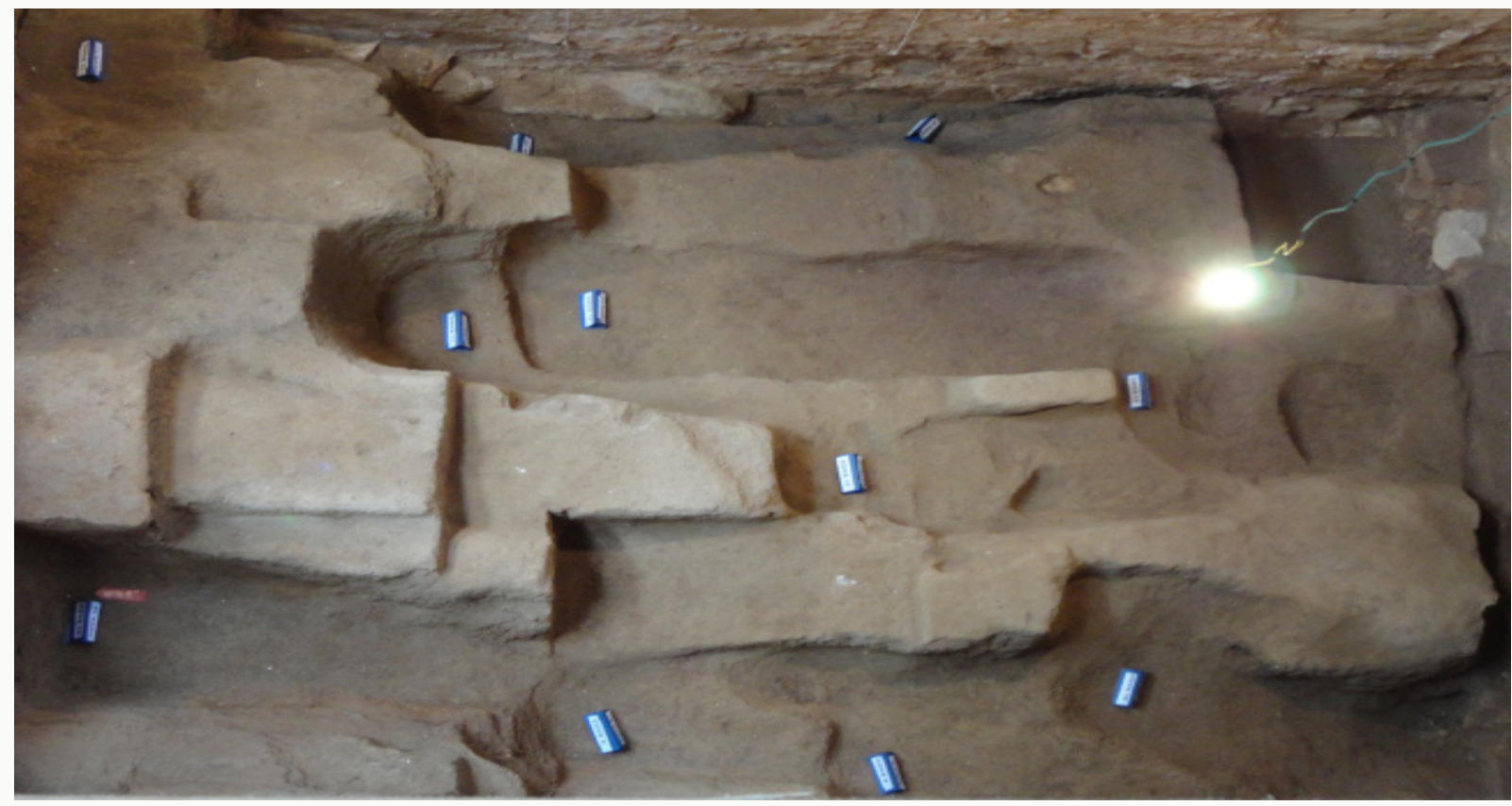

Fonte: Equipe de Arqueologia, 2012 


\section{Conclusões}

Os trabalhos de restauro e, por conseguinte, os arqueológicos, foram interrompidos em fins de 2012, por falta de verbas. ${ }^{24}$ Das áreas previstas para escavação em 2011, apenas a Área $\mathrm{A}$ e parte da vala de drenagem foram realizadas. Das áreas que não sofreram intervenção arqueológica, metade do claustro foi restaurado, incluindo os dormitórios, com a construção de uma academia de ginástica e de uma sauna. A grande área prevista para estacionamento foi desconsiderada, pois havia risco de desabamento da construção com o desaterro. ${ }^{25}$ Através de uma parceria feita com o Laboratório de Genética Humana e Molecular da Faculdade de Biociências da PUC-RS, as ossadas foram recolhidas para análise genética e morfológica, com a intenção de compreender como era formada a população da cidade no século XIX. Esses trabalhos ainda estão em andamento, tendo sido divulgados apenas resultados preliminares (Gonçalves, 2012).

Para além do importantíssimo resgate material resultado dessa pesquisa arqueológica, esta escavação serviu para trazer novamente à luz um espaço que foi significativo para a freguesia de Nossa Senhora Madre de Deus (posteriormente, vila e cidade de Porto Alegre) durante 78 anos, desde sua fundação em 1772. A construção do edifício do Seminário Episcopal (entre 1865 e 1888), a demolição da igreja matriz colonial na década de 1920 e a posterior inauguração da atual Catedral Metropolitana alteraram profundamente aquela paisagem, soterrando os remanescentes do antigo cemitério, e com ele mais de 27 mil ossadas. Serviu, igualmente, para estimular novas pesquisas (MEIRELLES, 2016), que buscaram uma análise mais crítica do pouco que existia escrito sobre este espaço

O cemitério da antiga matriz de Porto Alegre existia em um espaço pequeno, apertado que ficou ainda mais exíguo a partir de 1815, quando, conforme apresentado na nota 10 acima, o interior do templo deixou de ser necrópole. ${ }^{26}$ Entre 1772 e 1850, mais de 91\% dos óbitos ocorridos em Porto Alegre foram inumados no cemitério da matriz. Apesar disso, não foram encontradas sepulturas coletivas, ou qualquer outro indicativo de que este espaço seria tão desprestigiado como a bibliografia estrangeira e brasileira apontam. Embora o número de covas localizadas arqueologicamente seja muito baixo para propor generalizações, é possível afirmar por essa amostra que, ainda que de modo amontoado, cada morto possuía o seu lugar. Um dado que caminha nesse sentido é a existência de uma lápide datada de 1847 cujo corpo fora enterrado no cemitério, demostrando que lá havia sim sepulturas com identificação pessoal

24 O caso do golpe dado na Arquidiocese gaúcha por um ex-cônsul português foi bastante divulgado na mídia à época, e gerou, entre outros danos, a interrupção das obras na Cúria. Para mais detalhes, ver: <http://www.ihu. unisinos.br/noticias/46343-como-um-vice-consul-levou-r-25-milhoes-da-curia-metropolitana-de-portoalegre>. Acesso em: 07/10/2016.

25 Há boatos de que o restauro será retomado em 2017. O projeto teria sido todo revisto, descartando-se grandes intervenções em subsolo, previstas neste projeto de 2010. As salas no piso inferior que atualmente funcionam como depósitos serão transformados em um Museu de Arte Sacra, no Arquivo Histórico, e em um café, deslocando as áreas ditas públicas para a fachada sul do prédio, mantendo a área do claustro exclusivamente administrativa (térreo) e íntima (segundo piso).

26 Saliento que existiam outros locais minoritários para sepulturas em Porto Alegre no período de 1772 a 1850: nos arredores do hospital da Santa Casa de Misericórdia foram sepultados 445 indivíduos, entre irmãos da Caridade e pacientes do hospital; outros 27 cadáveres, em sua maioria escravos, foram sepultados na fazenda de Santa Maria Maior de Pedras Brancas, localizada no outro lado do rio Guaíba. Os livros de óbitos apresentam outras 75 pessoas sepultadas em nove locais dentro da Capitania, além de sete assentos nos quais o local estava ilegível, e outros 55 que não o informavam. 
(figura 18). Essa lápide, de arenito, com cerca de um metro e meio de altura, está quebrada na porção superior. Possui uma decoração simples, como moldura, na parte frontal, sendo a porção distal lisa. A inscrição remanescente diz:

Restos mortais d'Antonio Martins de Castro. Faleceo a 15 d'abril de 1847 com 29 annos d'idade". Busquei o registro de óbito de Antonio, onde consta o seguinte: "Aos quinze dias do mez de abril de mil oitocentos quarenta e sette annos nesta cidade de Porto Alegre falleceo de molestia interior, sem Sacramentos, na idade de vinte e nove annos, Antonio Martins Castro, solteiro, natural de Portugal, filho legitimo de Manoel Antonio da Cruz, e de Maria do Rosario; fez testamento. Foi encommendado por mim, e sepultado no cemitério desta Matriz. E para constar fiz este assento. O vig.o Thomé Luiz de S.za". ${ }^{27}$

Figura 18: Lápide de Antônio Martins de Castro

Esta é a única estrutura funerária remanescente do antigo cemitério da matriz. Nenhum resto de pedra parecido foi encontrado durante as escavações. Atribuiu-se a isso o fato de que a área escavada ser, provavelmente, o limite mais sul do cemitério, mais distante da igreja e, portanto, mais pobre. Esta lápide teria sido encontrada ao lado do antigo templo, em local de grande destaque e reservado à elite.

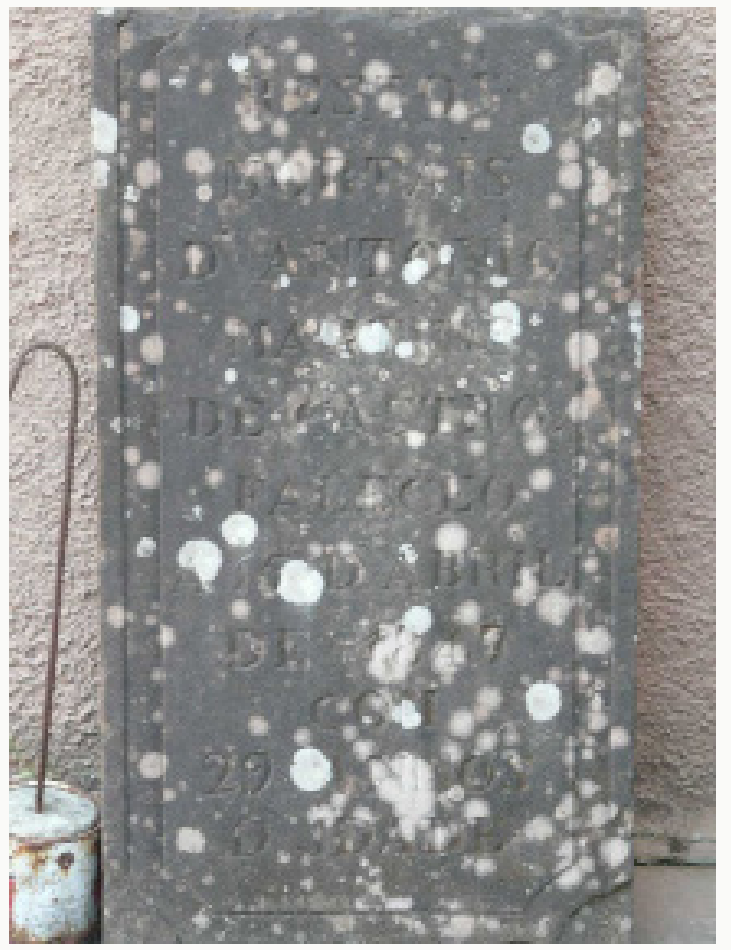

Fonte: Equipe de Arqueologia, 2012

27 AHCMPA. Livro 7ㅇ de livres da Madre de Deus, fl. 178. Cabe mencionar uma nota trazida por Augusto Porto Alegre: "Ainda a proposito do cemitério, diremos, que no anno de 1905, ao proceder-se obras de reformas nas escadarias que haviam entre a capella do Divino e cathedral, encontrou-se uma grande pedra com inscripção onde appareciam as lettras Ant... e os números 177...; é fora de duvida ter pertencido a alguma sepultura do primitivo cemitério na Praça do Palacio ou da propria Cathedral. O 'Correio do Povo' num numero de julho, narrou o facto em noticia por nós escripta". Porto Alegre, 1905, p. 234, nota 37. Procurei o jornal mencionado pelo autor, mas nada encontrei. É provável que a lápide citada por ele seja a mesma existente hoje na Cúria, apesar de o número mencionado não ser o mesmo, mas não há como ter certeza. As escadarias mencionadas pelo autor podem ser vistas na Imagem 3, acima inserida. 
Diferentemente do Rio de Janeiro, de São Paulo ou de Salvador, Porto Alegre é uma jovem senhora de 244 anos. Quando os enterramentos na igreja matriz foram proibidos, em 1815, fazia apenas quatro décadas que os santos conviviam com as ossadas dos reles mortais (desde 1772). ${ }^{28} \mathrm{O}$ cemitério atrás da matriz fora desde 1772 o local com maior concentração de cadáveres, onde, desde sempre, livres e escravos, pobres e não pobres dividiam o mesmo solo. A experiência tida no processo de escavação desse cemitério, brevemente exposta nessas páginas vem, portanto, demonstrar que esse espaço tão vital para as sociedades oitocentistas precisa, cada vez mais, ser avaliado a partir das idiossincrasias locais e não através do olhar bibliográfico estrangeiro, visto que este, conforme apresentado no início deste texto, tende a interpretar de modo muito limitado um espaço que deveria ser considerado central no cotidiano das povoações oitocentistas.

\section{Referências Bibliográficas}

ARIĖS, Philippe. O homem diante da morte. São Paulo: Editora Unesp, 2014. 837p.

BALÉM, João Maria, Padre. A Primeira Paróquia de Porto Alegre: Nossa Senhora Madre de Deus (1772-1940). Porto Alegre: Tipografia do Centro S/A, 1941. 152p.

CAPPELLETTI, Angela Maria. Relatório final Fase 1 - Monitoramento arqueológico nas obras de implantação da rede de drenagem pluvial e escavação para área de estacionamento no terreno da Mitra da Arquidiocese de Porto Alegre, sede da Cúria Metropolitana - RS. Volumes I, II e III, novembro de 2013. 525p.

CHEUICHE, Antônio do Carmo, Bispo. Catedral Metropolitana de Porto Alegre: Guia históricoartístico. Porto Alegre: Diagramme Produções, 2012. 143p.

DET SJUNDE INSEGLET [O SÉTIMO SELO]. Direção: Ingmar Bergman. Suécia: Film-Teknik, Stockholm, 1957. 1 filme (96 min.), som, p\&b, $35 \mathrm{~mm}$.

FERREIRA, Athos, Damasceno. Artes plásticas no Rio Grande do Sul (1755-1900). Porto Alegre: Editora Globo, 1971. 520p.

GONÇALVES, Pablo. Histórico da população de Porto Alegre através de ferramentas anatômicas: Um estudo preliminar. Apresentação oral de trabalho, PUCRS, 2012.

INSTITUTO HISTÓRICO E GEOGRÁFICO DO RIO GRANDE DO SUL (IHGRS). Cartografiia virtual histórico-urbana de Porto Alegre. Século XIX e início do XX. Edição em CD-ROM, 2005.

MACEDO, Francisco Riopardense de. O Aniversário de Porto Alegre. Porto Alegre: Unidade Editorial da Secretaria Municipal de Cultura, 2004. 172p.

28 Faço referência aqui a um artigo que escrevi discutindo a aplicabilidade da bibliografia estrangeira, principalmente francesa e portuguesa, para se analisar os contextos funerários brasileiros, muito mais recentes. Afirmo, dentre outros pontos, que enquanto na Europa se sepultavam cadáveres nos templos desde o final da Antiguidade, gerando assim de fato uma verdadeira acumulação de "miasmas" no interior das igrejas, a realidade brasileira seria diferente, não podendo ser analisada pela aplicação direta daqueles dados (Meirelles, 2015). 
MEIRELLES, Pedro von Mengden. Geografia Social da Morte: Uma análise espacial do Cemitério da Santa Casa de Misericórdia de Porto Alegre (1850). Monografia (Trabalho de Conclusão de Curso). Departamento de História, Universidade Federal do Rio Grande do Sul, Porto Alegre, 2010. 79p.

A criação do Cemitério da Santa Casa e o contexto da Reforma Cemiterial em Porto Alegre (séc. XIX). In: CENTRO HISTÓRICO-CULTURAL SANTA CASA. Santa Casa de Misericórdia de Porto Alegre: Histórias Reveladas IV. Porto Alegre: Evangraf; Ed. da ISCMPA, 2015, p. 130146.

Um terreno cheio de asperezas: O cemitério da Matriz de Porto Alegre no cotidiano da cidade (1772-1888). Dissertação (Mestrado em História). Programa de Pós-Graduação em História, Universidade Federal do Rio Grande do Sul, Porto Alegre, 2016. 243p.

MOREIRA, Paulo Roberto Staudt. Escravidão, família e compadrio: a comunidade escrava no processo de ilegalidade do tráfico internacional de escravos (1831-1850). História Unisinos. São Leopoldo, v. 18, n. 2, p. 312-337, maio/agosto 2014.

NASCIMENTO, Mara Regina do. Irmandades leigas em Porto Alegre: Práticas funerárias e experiência urbana séculos XVIII-XIX. Tese (Doutorado em História). Programa de PósGraduação em História, Universidade Federal do Rio Grande do Sul, Porto Alegre, 2006. 362p.

NEIS, Ruben, Padre. Porto dos Casais - Criação da Freguesia - Fundação de Porto Alegre. Porto Alegre: Metrópole S.A., 1972. 18p.

O RIO GRANDE DO SUL EM 1852. Aquarelas de Herrmann Rudolph Wendroth. Guaiba: Riocell, 1982. 61p.

PEREIRA, Júlio César Medeiros da Silva. À flor da terra: o Cemitério dos Pretos Novos no Rio de Janeiro. $2^{\circ}$ edição. Rio de Janeiro: Garamond, 2014. 193p.

PORTO ALEGRE, Achylles. Jardim de saudades. Porto Alegre: Officinas Graphicas Wiedemann \& Cia, 1921. 201p.

PORTO ALEGRE, Augusto. A Fundação de Porto Alegre. 2ำ edição. Porto Alegre: Livraria do Globo, 1909. 248p.

REIS, João José. A morte é uma festa: ritos fúnebres e revolta popular no Brasil do século XIX. São Paulo: Companhia das letras, 2009. 357p.

RODRIGUES, Cláudia. Lugares dos mortos na cidade dos vivos: tradições e transformações fúnebres no Rio de Janeiro. Rio de Janeiro: Secretaria Municipal de Cultura, 1997. 275p.

THIBAUT-PAYEN, Jacqueline. Les morts, l'Église et l'État: recherches d'historie administrative sur la sépulture et les cimetières dans le ressort du parlement de Paris aux XVII et XVIII siècles. Paris: Éditions Fernand Lanore, 1977. 456p.

VAILATI, Luiz Lima. A morte menina: Infância e morte no Brasil dos oitocentos (Rio de Janeiro e São Paulo). São Paulo: Alameda, 2010. 360p.

Recebido em: 08 de outubro de 2016.

Aprovado em: 31 de dezembro de 2016. 